A

\title{
LETTER
}

TO THE

RIGHT IIONOURABLE

\section{LORD SOMWPVILLE,}

ONE OF THE LORDS OF IIS MAJESTY'S BEDCIIMMBR, AND LATE PRESIDENT OF TIIE BOARD OF AGRICUITULE,

WITH A VICW TO SHEW THE

INUTILITY OF THE PLANS AND RESEARCITES

of

THAT INSTITUTION,

AND HOW IT MICHT RE EMPLOYED IN OTIERS

MORE DENEFICIAL.

WITH REMARKS ON THF RECENT COMMUNICATIOKS OF THE BOAKD, AND A REVIEW OF THE PAMPHLETS OF ARTHUR

YOUAC AND WILLIAM BROOKF, LSORS. UPON THE PRESENTHICH PRICE OF JKOVISIONS.

BI A SOCIETY OF PRACTICAL FARMERS.

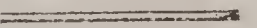

$$
\text { LONDON: }
$$

PRIATLE AND JUEZISHED BY

CEEORGE CAWTHOLE, XRATLH:ABRAPY, NO. I32, STRAND,

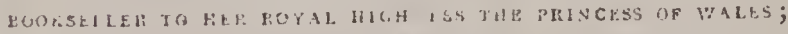

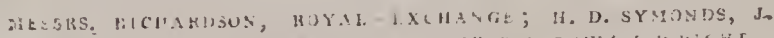

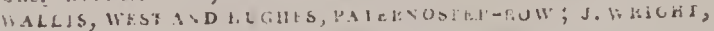
UICADILY; AN! P. HIIL, EDISBSLLCH,

$$
\text { Is̀o. }
$$

[PRICE THREE SHILLINGS, ] 


$$
\begin{aligned}
& \text { * El13 a J } 41921 \\
& \text { Desed } \\
& 37-0.212
\end{aligned}
$$

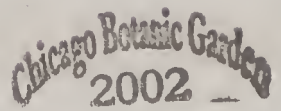


To

\section{THE READER.}

THE first part of the following Letter was intended for publication during the Presidency of the Noble Lord to wobom it is addressed; but the successize appearance of Mr. Young's Pamplutet, the Communicalions of ihe Board of Agriculture, and Mr. Brooke's work, induced the Authors to defer ils appearance, to enable them to add libe subsequent remarks; which circumstance will, they trust, account for the ruant of a more mellodical arrangement of the different subjects. 

A.

LET T ER

To

\section{LORD SOMERVILLE.}

MY LORD,

$W E$ take the liberty of addressing your Lordship, as late President, and now a very active member of the Board of Agriculture, on the behalf of ourselves and a very large portion of the inhabitants of the Island of Great Britain, to request you will condescend to inform us (as we understand the institution of that Board is a matter of public concern) of the nature and extent of the duties owed by your Lordship and the other members of the Board to the public; and, on the other hand, what co-operation you look for from the people of this country. At present, my Lord, we are totally in the dark 


\section{$[2]$}

upon the subject. We observe an annual vote by Parliament of a sum of money to promote the objects for which the Board was instituted:-here our information stops.

Had we seen any good resulting to the public from the exertions of the Board since its institution, with regard to the removal of impediments to agriculture, natural or artificial, or to the suggestion of improvemonts, we should have patiently awaited the result of your Lordship's more extensive lnowledge and active efforts: we have as yet seen nothing but two or three puny bantlings, that were offsprings of the late President, and died in their birth.

The efforts to which we allude are-The introduction of a Bill into Parliament for a General Inclosure of Commons, Common Fields, and Waste Lands, and the adopting Mr. Elkington's principle of Drainage.

With regard to the first, surely, my Lord, it wanted no ghost to tell Sir John Sinclair; that whatever measure tends materially to abridge the fees of the officers of the House 


\section{[3]}

of Commons, tends also to cramp the patronage of the Minister, and that such a measure is not only sure to be negatived, but even to bring down vengeance upon the head of the projector.

It is not for us, my Lord, to impute the removal of Sir John from the high oflice of President of the Board for his daring to persevere in agitating such questions, because that would be in part denying your Lordship's ability to fill the office. We, who are plain, blunt speaking men, think we know a little about the true interests of the country, and the best means of promoting them; and we cannot help observing, that an Aot fur a General Inclosure (could it be accompli,hed) would be totally unnecessary. All that is wanted is, to allow us to go to our representatives in Parliament, to gुet our Inclosure Bills passed without incurring the enomous expences of fees incidental to such a proceeding, which fees, for every parish or particular district, however small, amount from two to three hundred pounds, besides the 


\section{[4]}

further expence of procrastinated attendances of country agents in London upon the officers of both House of Parliament.

With regard to $\mathrm{Mr}$. Elkington's professed new system of Drainage, Prestly Bog, in Bedfordshire, (on the estate of the Duke of Bedford) we are informed, was the theatre upon which Mr. Elking ton's abilities were to be put to the test, and the great experiment to be tried.

The noble Duke, with that public spirit which in a peculiar degree distinguishes his Grace, paid the expences of the labour employed in the undertaking, amounting to near 10001 . for which, in the most successful cvent, he could not be repaid.

Scveral attendancess of the President and Members of the Board, and deputed Committees of Members, took place; they adjourned from London to the Duke's hospitable mansion at Woburn, in order, from time to time, to inspect the progress of Mr. Elkington's undertaking. After it was understood by the Board that its success was certain, 


\section{$[5]$}

and the poor man had been induced by the fairest promises to disclose his mighty secret, a vote of Parliament for 1000l. to be paid to Mr. Elkington, was moved for and carried; but whether the President or some sagacious Members afterwards discovered that $\mathrm{Mr}$. Elkington had hit upon a mode of bogdraining which had been practised by Dr. Anderson twenty years before, as well as explained and recommended in his works, he now finds the payment of the money obstructed by insuperable difficulties. Surely, my Lord, the engagement to pay $\mathrm{Mr}$. Eilington the money was honourable, and although you could not obtain it for him at an earlier period, it is hoped your Lordship will persevere in enforcing his claim upon your colleagues, till you obtain for him that for which the justice of the country stands pledged.

We flattered ourselves, at the first institution of the Boar I of Agriculture, that we should have been favoured, from time to time, 


\section{$[6]$}

with a list of its Members, and annually with a cheap publication of its proceedings.

We had formed an opinion that the first proceedings of the Board would have consisted of general investigations of, and enquiries into, the physical and other causes of the impediments to agricultural improvements. Permit us, my Lord, to mention, in a cursory manner, a few out of the multitude of subjects on which w'e bad. supposed the Board would at first have cmployed itself, viz.

DRAINAGE,

As to the too wet state of particular districts.

The breaches of banks and overflowing of rivers.

Oozings of springs.

The solie of internal water.

Overflowing of water from higher lands.

Rain-water retained in stiff soils.

Low lands subject to be overflowed by the sea. 


\section{$[7]$}

Injurious attempts at partial drainage in large districts.

Injuries sustained by the proprietors of different districts from not classing and incorporating themselves for the purposes of general and particular benefit.

Delay of improvement in not gaining land. from the sea, and partial washes at the mouths of rivers.

Injuries which proprietors of marshes sustain in dry seasons for want of supplies of fresh water.

Present plan of driving fat oxen 150 miles to be slaughtered for the Naviy.

The general want of drainage of large districts.

'The neglected state of his Majesty's forests.

Injurious plan of leasing the Crown Lands at high rents.

Present plan of inclosing common fields attended with unnecessary expences.

The same with commons and wastes.

Standing orders of the Houses of Parliament. 
By way of making ourselves more particularly understood, we shall take the liberty of enlarging upon some of the foregoing heads, but not with the presumptive view of adding to your Lordship's stock of knowledge ; a more accurate investigation of them would be an infringement of your Lordship's province.

By means of the prescriptive rights and privileges of the Crown in some cases, and of particular individuals in others, the drainage of one parish or district into the sea or river, whilst lands higher up and lower down remain in an unimproved state, is often, when sanctioned by legislative authority, very injurious, and productive of inconveniences past remedy, unless the proprietors can be induced to adopt well digested general plans for the improvement of the whole.

To class and divide large districts under the particular-heads of improvement, of which they are capable, and to induce the respective proprietors to incorporate them- 


\section{$[9]$}

selves, so far as to unite in general plans for carrying salutary measures of improvement into effect, would, we conceive, well become the members of a great national institution. They ought also to enforce them by the whole weight and influence of their power.

Many largedistricts there are of rich marsh land, near the sea, the produce of which is remarkably luxuriant and well calculated for grazing cattle and sheep, but which in a dry summer are of little value, for want of a supply of fresh water. To suggest the means ( for means there frequently are of cooling and refreshing tracts of this description with that necessary clement, in every season) is also an object of considerable national importance. Surely, my Lord, at a time when facility, economy, and dispatch in whatever regards the operations of war are so much studied by those who are entrusted with the powers and resources of the country, it was well suggrested by one of the county renorters, that it would be better (in the dog 


\section{[10]}

days at least) to carry the butcher 150 miles into the country, there coolly to slaughter the oxen, and salt them, than to drive them that distance, and convey the salt also to meet the butcher on the banks of the Thames; not to mention the heated, feverish condition of the animals, the expence of driving them, \&c. \&c. But, my Lord, in times like these, with respect to such trivial subjects, regard is paid more to him who speaks than to the matter which is spoken. But we bey pardon for this digression.

The maritime counties contain considerable tracts of land, which, in their present state and condition, are of but little value. These might be efficaciously drained or supplied with fresh water, as the exigency of the case might require, and might by these means be improved to a very considerable extent. Between the Humber and the port of Lynn there are districts containing, together, some hundreds of thousands of acres of the description now hinted at, which might in this way be improved and rendered of 


\section{$[1 ;]$}

treble their present value, over and above all the expences of carrying the plan into execution.

We now take the liberty, my Lord, of saying a few words upon the present state and condition of the forests. A great national institution, we conceive, onght to have represented to the Minister the extreme grievance which the public sustains by large tracts of land of this descrintion, even near the metropolis, and in populous manufacturing counties, remaining in the same rude state of nature in which they were before tiie country was inhabited. Investigations and reports of the innumerable abuses of this species of property are not wanting. The Commissioners of the late Land Revenue Board went through the enquiries with that industry and integrity, which will ever do them honour. They were assisted by $\mathrm{Mr}$. Fordyce, the present Surveyor General, and his deputy, Mr. Harrison, men of exemp ary industry and talent. They furnished reports, and every necessary document that could 


\section{$[12]$}

possibly be wanted for the purpose of extirpating abuscs, and for sowing in their stead the seeds of prosperity and plenty. Why such salutary measures have been procrastinated or rejected, it would, we repeat it, become an independent President of the Board of Agriculture to enquire..

The slow and regular progress of Agricultural Improvements promises nothing to modern financiers, who can with the utmost facility raise millions and tens of millions by voluntary loans, forced loans, tax upon income, Exchequer bills, \&c. After a fair and equitable distribution of the forests, there would remain but little wherewith to feed two descriptions of Ministerial followers in the respective districts, viz.

Those in receipt of emoluments, and those in expectation of them. By way of example, and in order to elucidate this subject more clearly to your Lordship, we will endeavour to give you a short history of the new forest in Hampshire, assuring your Lordship, that the same abuses, in proportion to their ex- 


\section{$[13]$}

tont, exist in the other forests, and that the same kind of concern for the public good is manifested in all.

We will not go far back for the commencement of this history, eight or ten years will be far enough. The whole perambulation includes about 96,000 acres, of which there are about 2,,000 acres chiefly inclosed and cultivated. The remainder consists of various wild productions, with here and there a patch of oak timber, irregularly distributed, and which is chiefly found in the vales, where the soil is evidently of a thicler or deeper staple. In other parts there are some patches of timber-like trees, which appear to have been planted very thick, from one to two centuries ago, and for want of having been regularly. thinned as they greiv up, are now mere spires, with proportionate tops. They appear like besoms at the mast-heads of ships, a practice used commonly to denote that they are on sale. Indeed it appears that the trees in this situation have been in a constant struggle or contention with each other for 


\section{[14]}

air, light, and atmospheric nourishment. The Forest-keepers informed us that there never had existed (any more than there does at this time) a power for the Forest-officcrs to thin or cut down any timber or timberlike trees without a warrant from the Lords of the Treasury.

Hence it appears, that their Lordships durst not trust the hand that plants with a discretionary power to improve by the common methods which bring private property to perfection. One of the Forest-keepers told us a story with which we were very much entertained, and we will endeavour to relate it. 'You observe, Gentlemen, on this side of the plantation ( said he) the trees are not so thick as at the place where you came into the coppice, but are much stouter, with pretty good tops, and the bark looks more healthy: One of the Gentlemen replied, - Yes, Keeper, this spot must have been planted thinner, and with more judgment than the other parts.' ' No, Sir, (replied the Keeper) not so. Observe the village of 


\section{$\left[\begin{array}{ll}15 & ]\end{array}\right.$}

below the wood, I have heard my father say that before he came upon the walk there was an idle drunken man had it, who used to lie in bed a-mornings whilst the lath-renders in yon village stole the young spires.' 'The Lords of the Treasury (replied our friend) ought to be thankful to the lathrenders for the judicious thinnings they thus gave the plantation.'

Other plantations of oak appear to have been made of much later date, at different periods within the last twenty or thirty years, and fenced round with posts, rails, \&c. at a very heavy expence to the public; but it is remarked by persons of observation in the forest, that no sooner were those fences compleated than they were pulled down again, with the connivance of those persons who, probably, wereat first employed to makeand erect them, and then from time to time replaced and repaired at an enormous charge. At length, the whole business turning out to be an arrant job, the main object of raising 
plantations of oak timber was necessarily abandoned.

The commoners' cattle and the wild beasts of the forests have now complete possession of those very spots which had been set apart for raising oak timber; and had that not been altogether the case, the persons who were entrusted with the protection of the new inclosures had found them extremely well calculated for raising and protecting rabbits, by means of which, before the fencing was abandoned, the young trees had been in a great measure stripped of their bark, and destroyed.

The remainder of this forest is open, producing, in detached patches, beech and holly, but generally fern, ling, sedge, and some times gorse.

About seven years ago a bill was brought into Parianent by the Ministry, (if we are correctly informed) without consulting the proprietors of estates, in respect of which they are possessed of rights of common, for 


\section{[. 17$]$}

dividing, allotting, and inclosing it, or otherwise appropriating, regulating, and arranging the several rights and interests. The bill passed the Commons, but upon some suggestions made by Lord T-, who is said to be a plain, blunt spoken Englishman, it was thrown out by the Lords. We believe his Lordship went so far as to call it ' a Ministerial job.'

Whatever might have been Lord T-'s opinion of the bill, or however exceptionable it might seem, or whatever job or jobs might then be suspeited, ive are very confident that the community would have been benefited, if upon any terms this large track of land had then been given up by the Crown, and placed in the hands of private individuals. It would ere now have been cultivated and improved, and every part of it would have been producing some valuable crop. As it now lies, it is a disgrace to the country, and its amelioration is certainly an object that calls for the attention of your Lordship and that of the Board at which you presided. 


\section{$[18]$}

We cannot help further remarking to your Lordship, that this forest must, in its present siate, be extremely unproductive, or the officers employed in it are like ravening wolves, for the whole of its revenue is not sufficient to maintain them.

Upon the bill before mentioned being lost, a Surveyor of experience and information was sent by the Lords of the Treasury into the forest, to investigate its condition, and the source of the discontents which the introduction of the bill into Parliament had occasioned; to find out what would satisfy the country, and to report the heads of such a bill as would be considered mexceptionable.

The Surveyor waited upon the Gentlemen and others in the neighbourheod of the forest, who had rights of common upon it, and proposed to them a division and inclasure, upon equal, fair, and equitable tcrins. We are informed that there was not one dissentient voice.

The report was made accordingly, and 


\section{$[19]$}

delivered to Mr. Secretary R-m, together with the heads of an intended new bill, agreeably to the negociation before alluded to. Unfortunately, however, it was not approved. The forest still remains in statu quo. Great objections have been made to incroachments of individuals upon this forest.

- But a true lover of his country canuot but rejoice when he sees them, because however poor the land so encroached upon might have been in its state of forest, no somer does it assume the shape and condition of private property, than from the exercise of industry and diligence it becomes a garden. We could not help admiring the well cultivated encroachments of Mr. Secretary Rose, near his seat at Cuffnells. Some people of shallow understandings had a great deal to say about his taking a batch of acres into his park, with a little fine oak timber on them; but doubtless this step was merely to preserve the timber. When it shall have attained maturity, Mr. Rose (who himself has been a Sea Officer) will, if his memory does not fail him, feel 


\section{[20]}

the necessity of sending it to one of his Majesty's Dock-yards; or, like the Cumberland Baronet, at the conclusion of a war, (should he chuse to be made a Lord) will subscribe a 7 is gun ship, to be built with timber to be cut in his oren park.

We believe it will appear, whenever the subject of obtaining an adequate supply of timber for the Navy shall be fully and fairly investigated, that the counties of Kent and Sussex are of themselyes nearly sufficient to uphold the Navy of England with oak timber.

Your Lordship cannot do better than to recommend the mode for marking of timber so successfully practised by others as well as by the Surveyor of his Majesty's Woods and Forests South of Trent, as it affords so fair and proper an experiment for Mr. Forsyth's method of healing new and old sores. Notwithstanding the ignorant and unskilful conduct of this Gentleman, for some particular reasons, the nature of which we shall not presume to guess at, but certainly not for 


\section{[21]}

the pre-cminence of his linowlcdge in the management of timber, he still retains his office; indeed there are some people so perverse as to say, that he would still retain it, were he to destroy all the timber in the forests.

CROIVN LANDS.

The apparent management of this species of property is in the hands of Mr. Fordyce, the Surveyor-General, with the assistance of his Deputy, Mr. Harrison; and were they to possess a discretionary power to act in all cases, we firmly believe the business could not be placed in better hands. But we have too much reason to apprehend that their powers are extremely limited.

It appears to be the principal part of the present system to suffer the leases of the estates to run out, or very nearly so, before renewals take place, with a vierv, it is presumed, to raise the rents as high as possible. We shall not venture to agitate the quistion 
as to the justice or injustice of this proceed. ing.

Whether the ancestors of many of the present lessees had not, as a recompence for their public services, received grants or leases of manors or lands, with implied assurances that their leases should be renewed, from time to time, upon easy and liberal terms, it is now difficult to determine, but it is well known, that many of the heads of families have considered the renewal of the Crown lcases as certain provisions for younger children, and devised them accordingly.

It is most certain, that it would best prow mote the interest of the community, that such measures should be continued, or that either the Lessees should purchase the interests of the Crown upon equitable terms, or the Crown purchase the remaining interests of the Lessees.

Unless one of the three plans above mentioned is adopted, the actual occupier will inevitably be racked up during the term, and 


\section{$[23]$}

at the end of it the property will be likely to be plundered, because he will have little encouragement to pursue measures of rationa! and permanent improvement to the soil under a Lessee, who, to obtain any advantage to hiniself, must bear very hard upon him in point of rent. It is needless to enumerate to your Lordship all the particular, disagreeable, and distressing circumstances that occur under this head.

It is precisely this mode of leasing land which has rendered the agriculture of Ireland so much in point of improvement below that of England, and it has been one of the chief sources of the miseries of the lower classes of that prople, and in no small degree of that tumult and confusion, which has so recently and unfortunately pervaded that distracted country. 
.The business of inclosing common fields has gone to a considerable length in England, and would yet increase, if the blessings of peace were to be restored to us, and money could be more easily raised upon private securities, and more especially if the expences of carrying the measure of dividing and inclosing into effect could be brought within a reasonable and moderate compass. We have already observed to your Lordship one point of expence which ought to be dispensed with. For small parishes, or districts, it wonld be adviseable to appoint only two Commissioners, under an Act of Parliament, with power for them to call in an umpire in cases of disagrcement.

If your Lordship were to turn your attention to this subject, it would probably strike iyou, that the appointment of an Attorney "is Clerk to the Commissioners of an inclosure, vith equal fees to themselves (the general p ractice) for writing not more than twenty 


\section{$[25]$}

or thirty lines in a week, might be dispensed with.

It might not be unworthy of your Lordship to cause enquiries to be instituted with regard to what particular soils and situations of common fields are unlikely to derive profit from dividing, allotting, and inclosing, under all the various circumstances of expence. We could point out to your Lordship soine large districts which are incapable of any material alteration, from the present system of husbandry. The exchange of lands, and the laying of each proprietor's estate more compactly, would probably, in such situations, be the most desireable plan.

\section{COMMONS AND WASTE I.ANDS.}

Is the due apportionment of this species of property among the respective proprictors, we presume your Lordship will suggest the necessity of introducing a clause into Acts of Parliament for dividing, allotting, and in- 


\section{$[26]$}

closing; that upon a requisition from the Proprietors to the Commissioners, a proportion of such property should be sold, for the purposes of paying the expences of passing the Acts, and carrying them into execution. This step would give the proprietors of small allotments an opportunity of entering upon their new estates without incumbrance, a matter of the first importance.

STANDING ORDERS OF THE HOUSE OF LORDS RESPECTING INCLOSURES.

THis, my. Lord, is a subject of great importance to the public, and, we conceived, would have claimed your Lordship's early and most particular attention, in order that, by your superior judgment and information, the active zeal of a few Members may not mislead those who are not well informed upon the subject, and thereby check and cramp the execution of the busincs, by fixed rules, which often tend to the extreme injury of 


\section{$[2 i]$}

those for whose benefit they are professedly made.

In the last sessions of Parliament some standing orders were proposed, and many of them died as soon as they were born. At length the following were recorded:

- Resolved,

' $\breve{J} o v i s, 27^{\circ}$ die $\tilde{J} u n i j,{ }^{1} 799$.

- That the standing order of the House, of the 27th of April, 1774, which directs, That, in all bills for inclosures there be inserted a clause, compelling the Commissioners to account for all monies by them laid out, and assessed on the parties concerned, in the said inclosures, be repealed.

\section{- Resolved,}

- That, in all bills for inclosures there be inserted a clause, compelling the Commissioners to keep, at the office of their Clerk, a book of accounts, open, at all reasonable times during the progress of the inclosure, and till the accounts are finally settlea, for 


\section{[28]}

the inspection of any of the Proprietors: which book shall contain an entry of the particulars of all sums of money raised or expended by virtue of any powers granted by the Act; under a penalty, on such Commissioners or their Clerk, for neglecting ö refusing the same: and also a clause, providing that all monies to be raised under and by virtue of the powers contained in such Act, shall, as often as the same shall amount to the sum of fifty pounds, be paid into the hands of some Banler, or of such other person or persons as shall be approved by a majority of such proprietors; and that no monies be issued out of the hands of such Banker, or other person or persons, without an order of the Commissioners, specifying the person to whom the same are payable, and the service for which the same are due; and that the balance, if any, upon the final settlement of accounts, shall be immediately repaid to the land owners, in proportion to the sums respectively paid by them : and also a clause, providing that the final award shall be read, 


\section{$[29]$}

and signed by the Commissioners, in the presence of the Proprietors, at a special General Meeting called for that purpose, of which ten days notice at least shall be given in some newspaper, to be named, circulating within the county; and that such àward shall be proclaimed the next Sunday in the parish church ; from the time of which proclamation the same shall be considered as compleat for the purpose of appeal.

- Ordered,

- That the last of the said Resolutions be made a standing order of this House.

J. LEY, CL. D. LOM. COM.'

The Members who proposed and seconded the above orders could not be well acquainted with the necessary business of inclosures. The Proprietors of a parish, destined to be divided and inclosed, cannot carve for theriselves; they must commit their whole property into the hands of Commissioners. If they are men capable of being corrupted, they can, in their 


\section{$[20]$}

valuations, divisions, and allotments, injure one Proprietor and serve another, to the amount of thousands of pounds, without a possibility of detection; but in the matter of raising and expending the necessary money for carrying an Act into execution, the meanest Proprietor may exercise a judgment when he sees the Commissioners' accounts in the usual way.

The House of Commons prescribes a rule by which the Commissioners are not to be entrusted with 501 . and also allows an interference on the part of the Proprietors as to the conduct of the Commissioners in the progress of the business, and before they have made their final award; which is by some considered extremely improper, as also any interference with respect to the Commissioners' award. If it is to be made a subject of appeal, where is the business of an inclosure to end? 
We have been informed, that for some time past your Lordship, and certain active Members of the Board, have been chiefly occupied in an enquiry into the comparative excellence of certain varieties of sheep. We cannot help observing, that it appears to us that the enquiries and experiments of your Lordship and the Board have not been sufficiently extended to the several properties of the different varieties, so that no decided conclusions can at present be formed of the superior excellence of any particular sort.

The late Mr. Bakewell made some attempts at a critical investigation on this subject, but proceeded only a little way, his attention being chiefly directed to one or two points, but most particulariy to a mixture of breeds which, in his opinion, possessed, in the great- est degree, a propensity to lay fat upon the outside of the carcase at an early age. But the public has too much reason to apprehend that Mr. Bakewell's experiments were frequently partial and undecisive, though, never- 
theless, extended far enough to render his endeavours highly profitable to some of his disciples. This particular sort is described as the New Leicester, and now celebrated by certain amateurs as the most perfect and proftable breed of sheep in the Island, and unrivalled also, except by those from the South Downs.

We shall, for the present, beg leave to suggest to your Lordship, that it might have been attended with more advantage to the public, if the active Members of the Board had first made a greater progress in experiments, and not stopped at a comparison of the most valuable properties in such varicties, as they then appeared, but proceeded to judicious selections out of many improved varieties, in order to examine the effect of blending the greatest number of the most valuable peculiarities together, and concentering them in one breed, which, on some soils, may be extremely beneficial; still taking care to preserve distinctly the improved original breeds, which, according to our observations on the laws of nature, appear 


\section{[33]}

not to have been prescribed in vain, but adapted to the different soils upon which they are found. We cannot but lament a rage which prevails in several counties for destroying their peculiar breeds, and introducing the South Down and New Leicester, upon the mere example or sugrestions of those persons who, it is feared, have not made suficient experiments of the comparative value of either.

\section{LAND VALUERS, \\ COMMONLY CALLED \\ SURVE.YORS.}

The office of a Land Surveyor was formerly confined to the geometrical operations of admeasuring and planning landed property : in the present age a tribe of men have sprung up, who have united with that office a kind of mysterious juggling art, in ascertaining the value of land, commonly known by an appellation, not very inaptly called ' land tasting.' In the country it is assumed 


\section{[31]}

by mere measurers of land, schoolmasters, and broken inmholders, not possessing the least practical knowledge in the cultivation of land. Can any thing be more ridiculous than the calling a modern auctioneer from the pulpit inGarraway's Coffec-house, or from the pevement of London, to value landed property ?-Men whose habits of life could not give them any opportunity of understanding any of the leading principles upon which their qualifications ought to be founded. The better part of such practitioners are a sort of practical husbandmen, who, from a restless disposition, neglecting their own original occupations, assume this office; but who, from their confined situations in particular districts, are, for the most part, destitute of that general knowledge which is absolutely requisite for the forming a true estimate of the value of landed property. In the metropolis, valuers of land are as plentiful as death-hunters; every upholsterer, feather-bed beater, and auctioneer, from Whitechapel to Hyde-Park-corner, will un- 


\section{[35]}

dertake to value and let land in any situation, and in any quantity. Men to whom, from their habits of life, you ought to pay no attention, in concerns of so much general, as well as private importance.

Your Lordship's good sense will readily admit that the qualifications for the office of a general Valuer of estates, and a Commissioner upon inclosures, can only be found in men well versed in the praclical husbandry of the mest improved counties, as a stock on which subsequent observation and general experience in the management of landed property should be grafted.

We presume that this subject demands the most serious consideration of the Board. We recollect your Lordship's address to the Board, dated 8th of May, 1798, and the pledge you therein gave to the public, that you would endeavour to stop further profuse publications on husbandry, and most particularly county reports, for a considerable length of time. Nevertheless, in the next year apfeared the publication of your Secre- 


\section{[36]}

tary's ' General View of the Agrriculture of the County of Lincoln,' 155 pages, price nine stillings in boards.

Whether your Lordship and the Board expected to obtain fair and impartial statements, in order tc-improve the agriculture of that county by the subject matter it contains, or to relieve the impaired state of its fund, by the sale of the book, we venture to presume that in every view you have equally failed; the public opinion has long been decided upon the agricultural abilities of the author, and though he was eitertained with civility by some of the resident agricuitural amateurs of that county, his suggestions and opinions were generally received with as much distrust as if they had issucd from one of the unfortunate residents with the eminent Doctor* at Creatford. We have seen a pre-vious publication on this subject, published by the authority of the Board in 1794, from the reports of $\mathrm{Mr}$. Stone; and though we

* Dr, Willis. 


\section{$[37]$}

do not presune to enter fully into a comparative estimate of the merits of the respective reporters, we cannot but observe a great contrariety in their information upon very many important agricultural subjects.

We have perused Sir John Sinclair's plan for the establishing, by subscription, a ' Joint Farming Stock Society.'

We cannot look at this scheme in any other light than as a chimerical project. Were all the gain which the proposer promises to subscribers to result from it, monopoly would be the natural consequence : and the public might consider extended farming combinations in the same light as they do the East India, or any other overgrown trading company, with only this distressful difference, that the monopoly of the latter extends only to luxuries, which we may purchase or reject; the other to the mere necessaries of life. If Sir John's plan sicceed exactly to his present expeciations, we shall probably, in particular seasons, find old beans to be as dear as nutmegs. 


\section{$[38]$}

The only fair mode of reasoning upon this subject is by analogy. There is now scattered about this island a variety of farms, on various soils, in the hands of individual noblemen and gentlemen, which may very properly be called experimen'al, upon which every now scheme, every new grass, grain, implement, and mode of cultivation are attempted. What has been, in most cases, the result, may we pronounce in one word of truth-it is disappointment. Have any of those amateurs produced to the public a journal of the proceedings upon any one spot, with a debtor and creditor account of profit and loss?

Indeed we have scen one gentleman make the attempt, and he, unfortunately, forgot to bring the annual rent of his land into the account. From the ordinary farmers, who form the great mass of practitioners, the main resources are to be drawn. By them the markets are to be regularly supplied: and those are a description of men who must be shewn, by the plainest of all demonstra- 


\section{$[39]$}

tions,--their own occular proof,- - that the adoption of any new plan, in opposition to their daily practice, will be beneficial to them, before they can be persuaded to adopt it. With them demonstration only will bring conviction, and will do more in five minutes than all the boolis that have been written on the subject. It is impossible for any one to form a true estimate of the ability of a practical husbandman but one who is well qualified in that art.

This observation applies alike to men in all arts and professions; and until a knowledge of practical husbandry is inculcated at an early age, when the mind is unincumbered with other pursuits, and when suficient leisure is afforded to observe all the minutia of the farmer's practice and plodding, for three or four years, at the plough tail, we apprehend it to be very difficult to find a nobleman or gentleman of large landed possessions (whose education and habits have been directed to other pursuits) well qualified in the niceties of agriculture. We 
have viewed several farms, which, for some years, have been in the hands of noblemen and gentlemen of great good sense, who are actuated in every pursuit by motives of benevolence to their country, and to every individual around them, and have remarked that they do not possess an acre of land either so well cultivated or so productive as it would have been in the hands of a good practical husbandman at one-fifth of their expence.

There are those who, upon a modcrate estimation, may be fairly pronounced to expend some thousands per annum more than, the rent of their land in the more attempt to improve the agriculture of the country; and, without illiberality, it may be truly asserted, that so far from their experiments producing general good to the neighbourhood where all their great schemes of farming are carried on, they have had, in many instances, a contrary tendency. The ordinary farmer keeps his eye upon the accumulated expences, and watches, with a malicious pleasure, the failure of crops; and even attributes such, as no 


\section{[ 4.1$]$}

human foresight could prevent, to the errors of practice. At his market dinner he does not forget to proclaim how long the fat ox was feeding, which gained the prize, and how much more than his worth he consumed of pampering provender.

Since Sir John Sinclair has thought proper to make a quotation from the works of the agricultural hero of Bradfield-Hall, in Suffolk, it may not be considered inapplicable in this place to notice that precious spot, though indeed it may be considered by some as rude in the extreme, with unhallowed feet to tread on such 'classic ground;' but, my Lord, has it not been held out to the public as an experimental or a bigbly finished practical farm, for upwards of thirty years? Can a practical husbandman be found in the whole county of Suffolk, who will stand up at your Board, and assert, that he has derived one atom of benefit from any thing which Mr. Young has there attempted to put in practice, except a conviction of the 


\section{[. 42]}

expediency of following in every thing the direst reverse of bis example? *

We now beg to take leave of your Lordship, with a recommendation to you and the other Members of the Board of Agriculture, that instead of contributing to the establishment of experimental farms upon Sir John Sinclair's plan, which, in all human probability, will have as little success as your Secretary's mothod of feeding pigs, you endeavour to cultivate, near your respective seats or residences, certain portions of land according to the most gencrally adopted sizes of farms in your several neighbourhoods, upon plain, rational systems of agriculture, agreeably to the nature of the respective

* This gentleman, at a certain time, conceived that the best mocle of feeding hogs would be upon boiled potatocs: he accordingly provided a large copper for the purpose, and determined personally to attend the frrst part of the experiment. The swine were summoned to the caldron; and as Mr. Young conceived they would thrive best fron? taking their foud in the hottest state, it was so delivered to them; but he mistaking the wrigling of their tails, then a symptom of e treme pain, for that of plcasure, supplied them plenti2u.ly with fresh and hot pitatos, till he killed them all. 


\section{$[43]$}

soils. We request you to unite the best known and approved practical husbandry with the improvement of the species of sheep, and other stock, which are peculiar to the respective districts. We also exhort you to publish annually a journal of furming proceedings, and a debtor and creditor account of profit and loss, taking especial care not to leave out the rent. This we humbly conceive to be the most rational mode of immediately improving the agriculture of the country, and of producing an accumulated fund of food for man and beast, and of general prosperity and riches.

There will always be found noblemen and gentlemen of opulent fortunes, who will devote a portion of their time and property to experimental husbandry, a thing that mey easily be accomplished by setting apart a certain portion of land merely for that purpose, and totally unconnected with practical husbandry. 


\section{[44]}

\section{OBSERVATIONS}

UPON THE

\section{PRESENT HIGH PRICE OF GRAIN.}

It may perfeetly agree with $\mathrm{Mr}$. Arthur Young's interest, in the good opinion of his political friends, to ascribe the present high price of bread wholly to the failure of the last year's crop, because, if he can persuade the public to believe his doetrine, we well know that the popularity of his friends will be very little, if at all, affected by it. We have perused his pamphlet, entitled ' The Question of Scarcity plainly stated, and Remedies considered, and we are surprized that Mr. Young has the audacity to imagine that he can mislcad the public opinion from the principal causes of the present calamities, which the middle and lower orders of the community are compelled to bear, and con. ceal the linowledge of his deceptive assertions, pretended statements, and unfounded 


\section{$[45]$}

calculations from one man of common discernment!

Whatever reflections Mr. Young may attempt to throw upon gentlemen who have honestly and fairly stated the information they have received, respecting the last year's crop of corn, from unprejudiced Stewards, Agents, and correspondents in the country, or however he may attempt to represent their employers as 'short-sighted supporters of Government,' because they are honest encugh to divulge the fact, that the deficiency of the last year's crop did not amount to more than one-fourth of the average jearly crop, and that there was three montlis stock in hand at the last harvest, will little affect them; their reports are entitled to at least as much credit as Mr. Youngy's, and their means of obtaining information not more exceptionable. If Mr. Young had published the circular letter he sent to his Agents, of whom he meant to obtain information upon this subject, it might probably appear that they had inferred something of Mr. Young's 


\section{[4.6]}

motive for the enquiry, and the result he wished to establish; however, it is not very material for our argument. It is no less probable that the persons, of whom he gives a list, as having been applied to by him in the several counties he mentions, gave their opinions very hastily, not being allowed sufficient time to ride from village to village to collect the necessary documents to enable them to draw a fair average; therefore, we apprehend that Mr. Young's information upon this important subject is mercly matter of opinion, and no more to be relied upon than that which might have been obtained on any market day, at Mark-Lane, by making the enquiry of sixty-seven persons promiscuously brought together from twenty-five counties *ut of eighty-five, and who were not previously informed of the motives of the enquiry.

The oblique reflections upon the authority of Mr. D_ , of Wiltshire, one of the best

* See Pamphlet, p. $3^{8}$. 


\section{$[47]$}

informed agriculturists, an excellent Steward, and a man of great integrity, are not handsome; and they appear the more censurable in the eyes of those who are well informed that Mr. D- and Mr. Young differ exceedingly upon agricultural subjects, and that they had a personal difference, some time since, at an agricultural meeting of the Bath Society.

We have too much reason to believe that the present high price of corn, as well as butcher's meat, do not proceed principally from a failure of the last year's crop, but from other causes, which have their origin in the war in which we are engaged.

The ill efferts to the community of an over strctched and too far extended paper currency were, to a certain extent, pointed out by the justly celebrated Adam Smith, in his - Enquiry into the Nature and Causes of the Wealth of Nations;' but that excellent writer conceived that it was an evil of no great extent, and that it would soon correct itself, because the parties who should exceed their 


\section{$[4.8]$}

capital in money by such extended circulation of paper, would soon be blown up, and thereby receive the reward of their temerity, before the community could suffer much loss. It never entered into the mind of this political philosopher that any Governor and Company of the Bank of England, who, in their official capacity, ought to stand the firm unbiassed guardians and trustees of the public, should take upon themselves to enter into a political alliance, and suffer the trea. sures of the public to be appropriated to speculative purposes; or that a majority of men, the best informed, and possessing the greatest interest in the state, should, at any time, sanction a measure so unpromising and unprecedented.

This great national institution being thus made auxiliary to political purposes, and. being relieved from the necessity of paying cash for its notes, may, from the apparent pliability of its Principals, be tempted to extend its loans and its discounts to an amount that may ultimately prove hurtful to the 


\section{[49]}

community. It is not altogether unknown, that Co:ıntry Bankers, although, no doubt, with a view only to extend the circulation of their paper, have, by their accommodations, enabled selfish individuals to monopolize to a considerable extent what they would otherwise have been obliged to send to market.

We must, however, for the sake of truth and candour, confess, that dealers in corn, Millers and Bakers, are not at this time monopolizers to any great extent. The growers of corn having, for a few years past, become more opulent than heretofore, are, at the present time, enabled to circumvent those gentlemen, and avail themselves of their previous example, by holding it back from market, and thereby deriving some part of the advantages which otherwise would be reaped by them; for, if a farmer, who has his corn in hand, is pressed for a sum of money to pay his rent, or for any particular occasion, he may be easily accommodated at a Country Bank. 


\section{[50]}

We are well aware, that whilst we are engaged in so extensive a war there cannot be any very large importations of grain, so as to lower the price very considerably; and if such circumstance was to happen, we shall only share the fate of all other speculators in our turn, of having the chances run a little against us.

If there had been a real scarcity at the time Mr. Young wrote his pamphlet, by this time the stock in hand would have been nearly exhausted; instead of which has it occurred, that any Miller or Baker returned from any corn market in England, who could not there purchiase as much corn as he wanted, at an high price? Or has any consumer in London, or in the country, on a market day, gone to market with money enough in his hand, who could not purchase a loaf of bread or a joint of meat? Taking the affirmative for granted, which is most true, where is the proof of the scarcity, and how is it to be proved? Is each individual to judge of it who possesses oxen, sheep, and corn in his hands? He would na- 


\section{[51]}

turally conclude there is plenty. Is the consumer to judge of scarcity, who ditily sees plenty of bread and meat in cvery market? No. It is left for Mr. Arthur Young to judge of it, who has received letters and reports from sixty-seven persons, residing promiscuously in twenty-five counties in England, who, have not given themselves much trouble in an enquiry amongst the occupiers of the districts in which they reside; and those men have informed Mr. Youngr that the last year's crop of wheat was deficient as seven in twenty, which is more than one-third of the usual crop.

That gentleman asserts, 'that through a very considerable portion of the kingdom wheat is almost uniformly thrashed out early in, or in the depth of winter, on account of cattle at that season doing better on the straw than they would do in spring.'

The fact is, that, with every farmer equal to his undertaking, (which description of them comprehends at least two-thirds of the occupiers of farms in England) it is a com- 


\section{[52]}

mon practice to stack their wheat out of doors, on hovels, which is seldom taken in for thrashing till May and the two succeeding months.

They have no dependence upon wheat straw for the maintenance of cattle in winter. It would be much within the line of truth to say, that more than one-half of the wheat in England is not usually thrashed till after Ladyday, the straw arising from which, in the country, is reserved for thatibing, and litter for saddle and other horses, and cattle, in the remainder of the summer and autumn, before they begin to thrash the new corn.

Mr. Young's recommendation of a more extended cultivation of Potatoes as food for man, and as a means of preventing future dearths, puts us in mind of a plan of Sir John Sinclair's when bread was at a very high price, five or six years since, which was corveyed to the public in papers circulated to the Grand Juries of all the counties,-recommending to the farmers to sow a larger 


\section{[53]}

quantity of wheat in the then ensuing season.

In that instance Sir John's zeal for the service of the public wanted the correction of a competent share of practical knowledge: he was not aware, that by such measure the subsisting covenants between landlord and tenant would have been broken, and that by sowing land out of the regular routine of cropping, and not in proper condition to produce a crop, they would not only have diminished the stock of grain then in hand, but that by such procedure, the land so sown would have been unproductive, reduced in its powers, rendered more foul, and consequently must have remained the longer before it could be brought into a state for prociucing a good crop of wheat. In short, from these, and a variety of other circumstances, it appeared to practical husbandmen, $t !$ at if Sir John's plan had been carried into effet, to the extent he advised, a great dearth, if not a famine, must have been the immediate consequence, if we could not have procured a very large 


\section{[ 54 ]}

snpply of grain from foreign countries; and it is much to be feared, that in the late winter and spring a large portion of land of these kingdoms has been sown with wheat by no means in a proper condition to produce an averagre crop; from which circumstance, the general product will, in the succeeding seasons, be the less.

If Mr. Young's plan of cultivating potatoes, to the immense cxtent he proposes, should prevail, similar consequences may be expected from it. It is well known to practical husbandmen, that potatoes are the most exhausting crop a farmer can cultivate; and when planted in upland land, which has been long in tillage, the quantity of the crop will bear an exact proportion to the quantity of manure immediately deposited in the soil for their production; therefore a farmer, who thus employs his manure, may consider it as taken wholly away from any possibility of benefit to his succceding crops, in a regular course of husbandry; a circimstance which must inevitably dclay his interest, and ultimately 


\section{$[\Sigma 5]$}

produce his ruin, if he has no other dependence for manure than from the consumption of the productions on his farm.

Potatoes can only be cultivated to advantage in situations where manure can be produced in large quantities, or readily purchased, to repair its exhausted condition with facility, or upon land newly broken upon from a state of pasture, from warped land in the vicinity of the Trent, Donn, or any other situations where land can be so improved, or where, from its own uncommon fertility, (if any such there be) it is incapable of being exhausted by any means.

Mr. Young admits, that wheat exhausts soil exceedingly; he therefore cannot, we think, safely recommend potatoes as a proper crop for cultivation upon a regular farm, in the same course of husbandry with wheat.

Mr. Young's recommendation, that cottagers shall be occupiers of land for the production of potatoes, with milk for their families, is a most plausible system in theory; but it is impossible to bring it into general 


$$
\text { [. } 56]
$$

practice. It may appear to have perfect strccess in the particular instances of Lord Winchelsea, Sir Cecil Wray, and many other noblemen and gentlemen who adopt it upon good land, at a very moderate rent, and who give the cottagers their stock of cattle; but where they must rent the land at a farming price, and purchase their own stock, there are insuperable reasons why it cannot answer.

Does Mr. Young calculate, that in order for a cottager to be possessed of a tolerably fresh milch cow, the year round, (and unless he is so provided his family cannot be supplied, or any profit derived from the land) he must be at all times provided with three head of neat cattle, that is to say, one of the above description, a stalc one coming in, and a young one at least to come in succession, to keep up his stocli. Ioes Mr. Young calculate how much pasture land such a man must occupy, at the average of twenty shillings per acre, in order to depasture his cattle in summer, and for the purpose of 


\section{$[5 i]$}

mosving for hay to sustain them in the winter? We presume it must take from eight to nine acres of such land. It camnot be supposed that a cottager shall be enabled to sell off a stale milch cow in the autumn, and then purchase a fresh one for his winter's supply ; because the waste of capital would ruin him.

Has Mr. Young calculated what is to be his fate when he shall have his modicum of hay spoiled by a wet season, from which no milk can be produced? an evil which very rarely befals a dairy farmer to the same extent; because, from the length of time he is harresting his hay, he is generally enabled, in the worst seasons, to gret some of it stacked in good condition, which he reserves for his milking cows, and that of the worst quality is used, without a ruinous loss, in the support of dry or barren cattle.

Does Mr. Young calculate, that cottagers' wives are seldom barren; and that where a woman has a young family, the first ten or twelve years after her marriage at least are 


\section{[58]}

taken up in nursing her children, and other domestic employments for them and her husband? She will then have but little time to take care of cows and her dairy: the milking at least must be performed by the cottager, which will be so much labour deducted from his general or particular employment. It cannot be presumed that he can maintain a servant: if so, all the supposed profit from the land is at once consumed.

Mas Mr. Young taken into his calculation, or made any allowance for losses in a cottager's stock? And has he taken into consideration the effects of sickness in his family? Whilst a cottager is possessed of any pro. perty, parish officers will not see the policy of affording him any relief, but will rather leave him to sell his cattle, to support his family in sickness, and to pay a doctor's bill.

Over and above the advantages Mr. Young proposes for the cottager, by means of milch cows, he allows him land whereon to cultivate potatoes.

The ultimate proposed success, carried to 
the full extent of Mr. Young's plan, would tend to make the cottager able to support himself and family upon his occupation, without any dependence upon his labour for the farmer, not much unlike the lower class of people in Ireland. In this case we should not have hands to cultivate the soil: the plough, loom, and sail would be unemployed, and when famine shall have reduced the numbers of the inhabitants to the scanty means of supplying the wants of those who remain, we must retum to the pristine state of things, thus described by Dr. Goldsmith:

"There was a time ere England's griefs hegan,

'When every rood of ground maintain'd its man.'

In our opinion, it would be a far better plan for every gentieman to provide necessary habitations, upon every estate, for the labourers employed in the cultivation of the soil, alloting to each a small piece of ground attached to it, for the purpose of producing potatoes and other esculent roots; indeed, as much (according to the nature of the soil) 


\section{$[60]$}

as he can be supposed able to cultivate properly atter his hours of toil for the farmer are expired. The landlord should introduce into his leases compulsory clauses, that his tenants shall either supply their labourers with milk the whole year round, or keep cows for them, at a reasonable rate; subject, from time to time, to be regulated by himself. This plan would be the means of rescuing the cottager from the ill effects of any risque, and lifting him above the probability of depression from fortuitous circumstances. It would also be a means of upholding the energy of his mind when working for the farmer, and of preserving his respect for him; which would not be the case were he to be possessed of an independent occupation, or to have it in his power (which Mr. Young proposes by his kind of agrarian law) to demand the possession of land for his particular purposes. When the cottager or labourer shall be possessed of the power to demand one acre, he will soon become dissipated, and take courage 


\section{$[61]$}

to demand nine, on the Painonian principle for dividing the whole of the landed property in the kingdom.

Although Mr. Young, in his Lincolnshire Report, recently published, condemns the payment of tythes in kind as a great national burthen, yet, strange to remark, he, in the pamphlet under our present review, recommends that mode as altogether unobjectionable! Theorists like this worthy Secretary frequently change their hy potheses!

We entirely disapprove of the plan $\mathrm{Mr}$. Young recommends for converting the Board of Agriculture into a Court of Inquisition, for the purpose of regulating the price of corn; nor can we think the Board of Agricuiture, which is chiefiy composed of noblemen and gentlemen of landed property, would, in point of decency, take upon them the office; a quality of which we do not accuse the versatile Effendi of the Board. We conceive that regulations on this point will be best to remain, for obvious reasons, where they now reside.

Mr. Young recommends a prohibition of 
the use of oats for horses kept for pleasure, as a means of reducing the price of bread. But it might as effectually, we presume, contribute to that end, if the making barley into malt was prohibited, and the distilleries stopt for a limited time. Beer and gin are not, stricly speaking, necessaries of life, though articles from which a very considerable part of the reventie is raised.

We perfecily agree with Mr. Young in the great advantages to be derived from a general inclosure. At the same time we presume to remark, that the landed interest has another very important work to perform, as a means of producing prosperity and plenty, which is, the application of all the soils already inclosed to their right use. If this were to be accomplished, many millions of acres, roluich are now pasture, and in their present slate producing very litile, would be profitably converted into arable, and rice versa; measures which would highly tend to the benefit of inm dividuals and the community.

Probably your Lordship will recommend to 


\section{$[63]$}

several Members of the Board to desist from enlarging their parks and pleasure-grounds, which are already enormously over-grown.

The relative price of corn and cattle will, in a given period, regulate themselves. There is a large portion of soil in these kingdoms, in the hands of Proprietors and occupiers, called ' up and down land, under the turnip and seed husbandry. When corn is at an high price, they keep it more immediately under the plough; and when fat cattle and sheep bear a higher comparative price than corn, they lay such land lown for pasture.

In the volume which Mr. Young has written, most professedly for the purposes stated in the title-page of his pamplet, "The Question of Scarcity plainly considered,' in which all the material causes of the present higin price of corn must have passed in review before his mind, it is very extraordinary that it escaped his recollection to remark, that great waste of the provisions for the sustenance of man must frequently happen where 


\section{[64]}

a great insulated nation is at war with several other powers; and, as respects the condition of this country at the present moment, a very extraoudinary degree of waste of food for man and beast must have happened in the late unsuccessful invasion of Holland, as well as in every other expedition undertaken by this country, and in the supply of foreign garrisons. He should have reflected also, that by the mprecedented increase of both our Army and Navy, there has been a greater number of inhabitants, than at any former period, subsisting on the productions of the soil, without contributing in the smallest degree towards its cultivation.

We beg leave to differ with Mr. Young where he says, (p. 74) that 'the heavy deep soils adapted to grass have been inclosed and applied to that use; whilst lighter soils, which are best adapted for the plough, remain uninclosed.'

We verily believe tiat if a minute inquiry was to be made, the reverse would be found to be the truest statement. Light convertible 


\section{$[65]$}

soils, capable of the turnip and seed husbandry, are the most unprodustive under the common-field management of two crops to a fallow'; but when inclosed are highly profitable in the production of corn, and in the breeding and feeding of cattle and sheep. This, when properly estinated, will be found to benefit the proprietors and occupiers equal to any soil whatever. Much has been said to recommend oxen to be employed in agriculture instead of horses; but we have not seen a perfect statement of the comparative advantages or disadvantages of either. We are of opinion, that on a large arable farm (of a soil where treading is not injurious) a farmer may kecp one or two ox teams, for particular purposes, without disadvantage, where road work is not required; but in the general business of a farm, the agility of the horse, and the saving of manual labour, will more than repay the farmer for the additional expence of his maintenance, and the casualties to which he is liable. We do not admit his declining value, 


\section{$[66]$}

whilst in the farmer's possession, but insist on the contrary; because a farmer, who knows his business, will always sell off his horses as they arrive at perfection, at six years old, and in their places purchase young ones; and this onght to be a source for the supply of gentlemen's carriages, stage-tvaggons, drays, \&rc. \&xc.

Surcly it must be a more gratifying reflection to a true lover of his country, and a well wisher to its prosperity, that the present high price of provisions does not arise merely from the partial failure of a crop of one species of crrain, but from a combination of causes which may with more facility be removed; because, if the former was actually the case, and agriculture could not be very considerably and rapidly improved, and the productions of our islands rendered more abundant, a further extension of population would rather bring famine than an accumulation of strength. We should then find ourselves at the zenith of our power. The surrounding nations would readily discover our 


\section{$[6 i]$}

condition, and would soon measure swords with us, having first calculated the extent of power, or combination of powers, necessary to effect our downfal.

$\mathrm{Mr}$. Young has written much upon the ill effects of promulgating the result of the inquiries made by the Committee of the House of Commons; probably if his pamphlet, now before us, was to be considered by neighbouring nations as coming from sufficient authority as to the real state of the country, it might do more mischicf than the publicity of the inquiry alluded to.

We have in a cursory manner perased the second volume of "The Communications to the Buard of Agriculture on Subjects relative to the Husbandry and Internal Improvement of the Country.' Wie shall therefore at present, trouble your Lordship with only short comments upon a few of the subjects of this prolix publication: for we do not volunteer the extreme labour of correeting and pruning the exuberances of the many theoretical communications contained in it. 


\section{[68]}

The ' Observations on the various modes of Inclosing Land, by Robert Somerville, Esq. of Haddington; first attracted our notice. We expected to find, under this head, some remarks which would have applied to the correction of many of the fundamental errors which are daily committed in the practice of inclosing. Instead of this, a considerable part of the book (114 pages) is occupied with descriptions and various plates of the different modes of constructing dead fences, and the raising of live ones. It is well known that the saying of labour, as far as is compatible with the principle of drainage, ought to be the main object in effecting this secondary part of the improvement of inclosing. With that vicw, the materials which the locality of the respective situations afford, at the cheapest rate, ought to govern the form and mode of fencing. But we are sorry to add, that the price of labour, timber, and weod, is now so extremely expensive in this land, that deal boards imported across the Eastern Cccan, are considered in the end, to 


\section{$[69]$}

be the cheapest and best of fencing rails for the new inclosures of Lincolnshire, Northamptonshire, Huntingdonshire, Cambridgeshire, \&c. \&c. and are generally adopted.

We must confess our disappointment in not finding in Mr. Somerville's observations any mention of an error daily committed by Commissioners of Inclosures, in laying out allotments in narrow strips of land, preserving a connection, indeed, with the ancient messuages, cottages, and homestalls, but, in effect, neglecting the greatest of all advantages to be derived from dividing and inclosing common fields, which is that of compainess, and the saving of duily labour, whereby proprietors of farms wosuld be enabled to build in cenlral situations. For this advantage the occupiers could afford, in most cases, (notwithstanding the high price of building materials) rather to pay 10 per cent. upon the money expended on such necessary central buildings, than to occupy slips of land, without any such charge. Farms thus laid out in squares are by far the most 


\section{$[70]$}

economical for fencing. We need not resort to figures, to calculate the advantages to be gained by shortening daily labour, when set in competition with the expence of buildings, as the latter may be estimated and fixed in the outset, and, when compleated, determines the expences for half a century.

It may be fairly presumed, that upon the inclosure of wet land, drainage is one of the leading objects of improvement to be effected; and therefore we cannot admit, that in the fencing of such land, (p.3.) any supposition should be allowed of live fences, of $a n_{j}$ description, being injured by too much wet. If that circumstance is not provided against, an inclosure cannot be beneficial for any of the purposes of agriculture.

With regarà to inclosures being beneficial, on account of the shelter thereby afforded to cattle and sheep, is not universally a decided point. In the rich marshes of Lincolnshire, the graziers and breecers are particularly averse to fences and shelter. "From experience, they are decided in opinion, that 


\section{$[71]$}

sheep thrive best where there are no fences, and are, in such situations, less liable to be fly-blown, or otherwise injurcd.

Mr. Tatlow's account of his embankment being cxactly upon Sir Thomas Hyde Page's plan, why insert it?

We cannot sufficiently admire the candour of Sir Charles Middleton, in his account of his farm in Kent; but probably his losses by grazing cattle, \&x. may have, in part, arisen from want of sufficient judgment in the person he cmploys to buy them in.

Kentish farmers, who have not a capital to work upon like Sir Charles Middleton, and who do not possess the means of procuring a considerable quantity of manure besides what is produced from the stock and crop of a farm, frequently make great sacrifices of their crops of grain in the production of hops. It would be wise, therefore, in the landlords in the hop countries, and in those where there is a propensity or temptation to the occupiers to cultivate hemp and flax, to restrain or limit them to the produstion 
of certain quantities, accorling to circumstances.

We have carefully perused Mr. Beatson's observations on cmbankments, and do not find any thing new in them; but we beg leave to recommend to that gentleman to be careful how he encourages persons who are occasionally employed to protect land from the overflowing of rivers, to increase the distance of the banks. This error was committed by Bishop Morton, an engineer of ancient date, but of great estimation in his time, who schened the construction of the banks of the river Ninc, between Peterborough and Wisbcacis. The space between them is called Morton's Lean. The banks are in many places nearly a mile asunder, that the water may cxpand itself from the channel of the river in times of flood, with a view to ease the banks; but unfortunately it appears from subsequent experience, that by such expansion sediment is constantly deposited in the channel or bed of the river, impeding the navigation, which would have 


\section{$[73]$}

been wholly prevented if the banks had been placed nearer to each other; because, if the upland water had been confined to a narrower channel, the bed of the river would thercby have been constantly scomred out by the sharpness of its current. The'other evil is of a most formidable nature. In consequence of the expansion of the water between the banks in timcs of floods, and at such critical moments should the wind rise, and blow for a given time in one continued direction, the water acquires a sca-like lashing of surge against the opposite bank, and is frequently the means of destroying it. In a very short space of time, some hundrcds of thousands of acres of rich and valuable property are inundated, which most probably never would have happened, had the banks been placed so as to confine the river within its proper course.

The estates of the greatest magnitude, which remain in this perilous condition, belong to the Duke of Bedford and Lord Eardley. 


\section{$[74]$}

- Essay on the various Modes of bringing Land into a State fit for Cultivation, and improving its Natural Productions.'

The perusal of this paper has excited every risible faculty we possess. The author seems to have set every practical experiment at defiance: To follow him through the 7 i pages of this extraordinary work, and to point out all the inconsistencies and absurdities he has advanced, and tc compare them with the rules of the plain practical husbandry of Great Britain, would occasion a work of much more extent than the whole of the communications now under review.

The schemes recommended by Mr. Headrick may be calculated for some distant region, explored alone by himself, where manual labour may be obtained without expence, and where marle, clay, lime, and, in short, every species of manure or alterative will flow in, and deposit itself upon the land intended to be cultivated, at his will and pleasure.

We cannot refrain from observing, in this 


\section{[.75]}

place, that, as the compilation of the Communications of the Board are made up of the same kind of materials as Mr. Young's Annals, the arrangement of this precious vo'lume was left to that gentleman's management, who, probably, consigned to it all such essays as were either too prolix or too little interesting for his own work.

Mr. Fenna's paper on Irrigation contains nothing new : his practice is now generally understood, and adopted. We observe a note of the Board to this effect, and therefore we are at a loss to account for the publication of that gentleman's remarks, except for the reasons above stated, or with a view that it should occupy a certain space in a necessary annual compilation.

Mr. Fenna's communications of his experiments with salt add nothing to our previous stock of knowledge of saline manures.

The Board cannot be ignorant of the great progress made by Lord Dundonald in the discovery of cheap preparations of saline manures for the purposes of agriculture, for 
which he has taken out patents, (to use his own words) ' more with a view to ascertain and prove that the discoveries were his, than with any view of reaping an emolument therefrom: We apprehend that the Board wotild not suffer in the public estimation, if it was to pay more deference and respect, than at present, to the works of this wellinformed, indefatigable, and ingenious nobleman.*

- Effects of the Equisctum Palustris upon Drains, by the Right Honourable Sir Joseph Banks, Bart.'

If the worthy Baronet, who, upon most occasions in life, has shewn a spirit of enterprize and perseverance almost unexampled amongst men of his rank and fortune, had,

* The following is an extraet from his Lordship's work:

- Sea salt is found to destroy snails, slugis, grubs, worms, \&c. by malking them void the contents of their bodies, evacuations tao powerlul for them 10 withstand. By these means not only their bodies, but their ciacuations soon becre foot for regerables. It is pirnci ${ }^{\text {... }}$ lly in this point of vicw that any benefit can be alt ibused to the action of the muriat of suda, or fure sea salt, upen ground.' 


\section{$[77]$}

during his leisure at Woburn in June 1798, taken an unprejudiced view of Prestly Bog, in that neighbourhood, the place where the great experiment of Elkington's bog-draining was to have been made, under the inspection of himself and other members of the Board, of which the public has heard so much in the original proceedings, already noticed in this publication, but of the result of which it remains totally uninformedwe say, had Sir Joseph Banks taken this view in the presence of $\mathrm{Mr}$. Elkington, his penetration would have led him to discover the most probable cause of Mr. Elkington's miscarriage, and he would have, at least, doubted whether it procecded from the choaking properties of the roots of the equisetum palustris, or from any other cause.

We are well informed, that after Mr. Elkington had staked out his drains, (as he could not personally attend to the execution of the cutting of them) the direcition of the labour was left to be executed, and was undertaken, by Mr. F_y, the Luke of Bedfor d's 


\section{[ 78 ]}

Steward at Wobtirn. When Mr. Elkington next viewed the works, he informed the noble Duke that a drain, in a particular direction set out by him, was altered in its course, which, in a great degree, caused the miscarriage of the whole work; and we can assert from the best authority, that the noble Duke expressed his displeasure at the circumstance.

We did not observe, in its place, upon Sir Joseph's letter respecting his attempt at the cultivation of rice, because it does not appear that it led to any decision of its practicability or otherwise.

There are theorists, dabblers, and smatterers in every art and every science, who, we presume, may not be inaptly compared to young or bad pointers in pursuit of game; wanting the discriminating power of scenting it, they keep their eyes upon those dogs which are staunch, who no sooner discover the prey than those we before alluded to thrust their noses forward before their superiors in skill, and of the ingudicions or inattentive sponts- 


\section{[ 79 ]}

man claim, and but too often receive, the rewards which in strict justice belong to others.

We have read with peculiar pleasure $\mathrm{Mr}$. Alexander Cumming's 'Observations upon Carriage Wheels,' and we very much approve of the conclusions which are there drawn, as the rcsult of his experiments; at the same time we cannot help observing that remarks upon the good effects resulting from cylindrical rims, in preference to those of any other construction, have been frequently made, both in and out of Parliament, ever since the construction of turnpike roads. Whence arose the exemption of toll, or increase of weight allowed, to a certain extent, for carriages with broad roicels. The construction of the conical rims has merely crept into practice, from time to time, from a combination of vulgar errors, which we sincerely hope $\mathrm{Mr}$. Cumming's exertions will for ever dissipate.

If the Middle-Lothian farmer had first described the effect of which the curl of the 


\section{$[80]$}

leaf of the potatoe was symptomatic, as applied to its bulbous root, it might have been acceptable to many reáders. But the surest way to produce what is generally called 'the Curl,' is to plant the seed upon land which has been long in tillage, without giving it a plentiful dressing of manure.

We presume that the planting of this root upon land which is intended to be converted from a state of grass to tillage, instead of 'paring and burning,' (a process so much extolled by Mr. Young) will produce more solid advantages to the community than all the volumes of theoretical farming which have been issued from the hot-bed of his imagination.

Your Lordship's 'Drag Cart, and Method of adjusting the Centre of Gravity of the Load, are notncw in the science of mechanics; nevertheless, upon referring to the note of the Board which accompanies the communication, the merit of your Lordship's discrimination and perseverance in its construction is fully explained. The skilful physician is 


\section{$[81]$}

not expected to have been the discoverer of the various drugs used in the art of healing. It is enough to establish his fame, that he has applied them with sufficient skill, whereby the ultimate object is attainel.

On your Lordship's 'Two-furrow Swing and 'Wheel Ploughs' we shall take the liberty of making some observations. It is more than twenty years since we first saw ploughs at work, of similar constructions, in the county of Leicester. A strong recommendation of them, on the one hand, and a degree of curiosity and a desire for improvement, on the other, induced several farmers in the adjoining counties to adopt them; and we are ready to acknowledge, that within that period they have been much used and approved there, as well as by Mr. Johnson, of Evesham, Mr. Score, of Buckland, and by Mr. Westphaling, of Radhall. But, my Lord, has any of the best practical farmers of Norfolk, Suffolk, or Essex adopted them? Has Mr. Cook, of Norfolk, or any of his 


\section{[82]}

numerous tenantry adopted them?* And since his Maj:sty's farms are mentioned, let us presume to cnquire of your Lordship whether Mr. Kent, who, we understand, has the chief management of his Majesty's farms in Windsor Park, sent your Lordship any commendation of them, in comparison of the Norfolk Wheel Plough? We apprehend he never will. But first, let us examine what is the intended effect of a plough. The intention of its operation is, in some counties, to preserve three material points; in others, two. In the counties of Norfolk and Suffolk, where the preservation of all land in a flat state at the time of fallowing is of great importance for the purpose of ploughing the land across, in contrary directions, ploughing it in straight lines is a material object. The second is ploughing each furrow parallel

* We presume a considerable length of time will elapse before Mr. Rodwell obtains a gold medal for the use of them. 


\section{$[83]$}

to the foregoing; and the third is keeping the bottom of the plough parallel, in all its points and bearings, to the surface of the earth, moving or stirring an equal depth of soil; in effecting which several points, the ploughs commonly used in the counties we have mentioned, have the undoubted preference over all others in England.

We shall now, my Lord, proceed to explain why ploughs of similar constructions to your Lordship's wereapproved and adopted in Leicestershire, Warwickshire, \&xc. \&x. In those counties the common ploughs were found extremely clumsy and heavy, the power to move them being placed at a great distance from the work; and which, whether upon strong or light land, four heavy horses, at least, but generally five, were employed to each plough. When the double-furrow plough was introduced there, the farmers found that the same power, which had been constantly before employed in performing their ordinary business, could effect 


\section{[84]}

double the work in a given time. This palpable circunstance of advantage, amongst men who had no otler comparative means of gaining information, was enough to induce them to adopt the double-furrow ploughs with great eagerness, and to continue the use of them until some fortunate coincidence of events shall produce a further experiment of the advantage of abandoning those for others still more beneficial.

We are extremely surprized to find the following statement in your Lordship's account of your favourite plough. 'An economical and spirited system of farming labour already prevails in some districts; in none more eminently, with respect to ploughing, than in Essex; on both banks of the Tweed; in Yorkshire, Suifolk, and Norfolk. Here it would be no object to invade the system aiready establishe $\rfloor$, for innovation is not palatable to fasmers; nor should the first deep ploughing in Kent give way to any novel system. 'Th. re can be no better husbandry.' Now, my Lord, if the husbandry of the 


\section{$[85]$}

districts you have mentioned is such, " that it would be no object to invade it,' that is, in other words to say, it is incapable of any material improvement, w'y altempt any where to introduce a 'novel system?' Would it not be far better to apply strictly those 'spirited systems' which are so successful in the districts your Lordship has mentioned? By a ' novel system' we apprehend you mean an untried plan. Where are the districts your Lordship alludes to, which must be devoted to experiment? IVe are inclined to believe that ayriculture is not yet carried half way towards the perfection it will in process of time attain, even in the improved districts before-mentioned; and it would be cruel in the extreme to deny the farmers there the chance of benefiting by the introciuction of your Lordship's pioughs.

John Hunter was a most excellent surgeon; but we may fairly presume he was a better carpenter than a practical farmer. Your Lordship las, it seems, adopted his ideas of 


\section{$[86]$}

deep ploughing. It is perfectly well known that some of the best corn districts in England do not consist of five inches of staple soil. If you touch any thing below that you bring up a determined enemy, break your pan, and render your land wholly unproductive. Deep ploughing can never answer but upon very deep staples, and even there the experiment of ploughing deep for one crop, and shallow for another, would still be a means of breaking your pan, and putting your soil into the condition of a cullender, where moisture, manure, mucilage, and all food for plants would sink below your reach. Very deep ploughing, even in a constant equal depth, in good soils, is generally more prejudicial to a farmer than the other extreme, because more than half his most valuable productions will thrive best when the seed and its subsequent roots lie near the surface, which, where habits of deep ploughing are generally adopted, are too much buried: besides, the more soil you have in action, the 


\section{[87]}

more manure must be applied in an equal improvement of it.

If your Lordship takes the trouble of comparing the construction of your doublefurrow ploughs with the single ones of Norfolk, as well as the work respectively executed by them, you will find, that the latter performs all the intentions before described, in the most perfect manner; that its action is steadier in the ground; that its coulter stands more prominent, with a greater proportionate length before the point of the share, to cut and clear away obstructions; that its bottom never inclines more to one side than to the other, or produces inequality of depth; that it is proportionately shorter in the body, and consequently passes through the soil with greater ease; that in stirring fallow land the wing of the share is always as wide as the extremity or hind part of its bottom, in order to cut the roots of all weeds it may meet in its progress, an intention for which it is superior to all other ploughs, steadily preserving a constant l:orizontal di- 


\section{$[88]$}

rection; that the horses are nearer their work than in your ploughs, which operates in its movement as a diminution of power ; that its furrows are of an equal size, a circumstance and effect which are not so common with your double ploughs; that two Norfolk horses, yoked double in a Norfolk plough, with one ploughman, shall perform more than half the quantity of good ploughing, upon any soil, in less than half the time that one of your Lordship's double ploughs, employed with double the pover, on any given quantity of land.

The double ploughs are said to carry furrows of nine inches and a quarter in the clear. We well know, that for the sake of apparently doing a great deal of work in a short time, a ploughman may carry furrows of near eleven inches, and even a foot, upon some soils, without deteetion or even observation from any one except a practical husbandman.

And although the challenge your Lordship mentions was not proceeded upon at Windsor, 


\section{[ 89$]$}

to decide the comparative merit of your Lordship's and other ploughs, we will undertake that the experiment shall be made in Norfolk or Suffolk whenever your Lordship pleases.

If the Secretary to the Board succeeds to his wishes, in exploding the drill husbandry, there will be no occasion for the use of ' $\mathrm{Mr}$. Ducliet's new-invented hand-hoe.'

Mr. Talbot Dillon, Under Secretary to the Board, we apprehend, might with more propriety have sent his errata to his printer than to have made it the subject of two pages in the Communications.

We have carefully perused the experiments and observations communicated to the Board by Sir John Call, Bart. and Robert Somerville, Esq. respecting the 'smut and blight of wheat,' and we are most decidedly of Sir John's opinion, which is so ably confirmed by his reasonings and experiments, viz. that the smut and bight of wheat are not communicated to the corn by any animalcula, insects, or corrosive substance, conveyed in 


\section{L90 ]}

the black powder, when mixed with the seed, but from the visitation of certain insects peculiar to particular seasons, which feed upon the ears of the wheat about the time the grain is forming. We have long been of the same opinion, and that any other powder, mixed with wheat, would be as likely to convey animalcula or destroy the succeeding crop. Sir John has left us nothing to add upon this subject. We are pleased with his remarks upon the atmospheric nourishment of plants, which may be in part elucidated by laying an onion upon a dry oak or malogany table, in the spring season, a situation of all others where it would be unlikely to gain any nourisliment from below. If he weighs it after it has been there a given time, say ten days, he will find a great and progressive accumulation of weight, which must alcne be derived from the atmosphere.

We observe the account of Mr. Donn's mode of kecping a farmer's ledger. It consists of seventeen pages; and we beg leave 


\section{[91]}

to observe, that any school-boy would have understood it, if it had been comprised in one. Similar statements may be found in almost all Mr. Young's calculations, tours, and reports.

We congratulate our friend, $\mathrm{Mr}$. Josiah Rodwell, upon receiving the gold medal, although he has practised no more in marling and claying at Livermere than have been carried into effect, thirty years ago, in various parts of Norfolk.

We perfectly agree with your Lordship upon the great advantage which will be derived to the country from the establishment of 'Provincial Farming Societies,' but we must confess we have our doubts whether the Board has arrived at a competent share of practical knowledge, to enable it to maintain a superior station, as a superintending power over the proceedings of practical husbandmen. Your Lordship must bear in mind that

$$
\text { ' Knowledge is power.' }
$$




\section{$[92]$}

We rccollect that the establishment of a provincial farming society was particularly rccommonded by $\mathrm{Mr}$. Stone in a publication in 1787 , cntitled 'Suggestions for rendering the inclosure of Commin Fields and Waste Lands a source of Population and Riches.'

From perusing the papers respecting the - Improvement of British Wool,' we are glad to find the subject in a train for being properly discussed and understood; at the same time we beg leave to correct an observation contained in p. 468 , "that our clinate is variable and raw, and that our dress o'cmands a stouter cloth than Turkey.' We readily admit that our climate is variable, and being variable, it frequently and very rapicily changes from hot to cold, and vice versa; but it does not follow on that account, that we should accustom ourselves to wear a "stout" dress at all times; but rather that we should change our diess according to the variableness of the weather. Nor is it necessary, in order to generate warmth, that any cloth 


\section{$[93]$}

should be 'stout,' (by which we presume the author means thick) or 'heavy.' Observe the mantifactory of Holland, Waistcll, and Co. where a blanket may be procured of English wool, which will impart more warmth, and not of one-tenth the weight of a pair of the best of those manufactured at Witney.

A palpable error is committed in the mention of a supposed fen of 7000 acres at LongSutton, * and the usaye of it. Some detached parcils of common were inclosed there about twelve years since, containing together, in their open state, 3.376 acres, but from which considerable deductions were made for roads.

The evil complained of there, whilst the commons were in an open state, was, that the farmers and graziers, who had no greater right than the cottagers, stccked them so hard with sheep, that the cow of the latter could not come in for a bite amongst them;

* Munkhausen, p. 45 . 


\section{[94]}

and that by a division and inclosure every man took an equitable share. The want of drainage was by no means a material or principal subject of complaint. These commons, which, previous to the inclosure, were ' all alive' with sheep, had been no sooner inclosed than the most considerable parts were immediately broken up and converted to tillage, and are now in a progressive state of impoverishment ; that is to say, the land will in a few years be ' ploughed out,' and laid down again to 'rest,' and sheep will then find their way upon it, when it will not carry half the stock it did when it was in a state of common.

We very much approve $\mathrm{Mr}$. Wilkes's account of his 'Iron Rail Ways,' having been eye-witness of the excellence of their construction, and we have no doubt that all the good he promises to the public will follow from adopting them.

We have made the foregoing comments upon different communications contained in the annual volume of the Board, with a view 


\section{[95]}

to keep the several subjects upon their proper bearings. Considering the prosperity of the agriculture of this country as the main source from which not only its happiness and riches, but also the daily food for man is derived, we trust that those persons who can discriminate between practical and theoretical notions of farming will not impute to us any other motives than those w profess, - the promotion of the public good. Guided by this principle, we conceive that it is the duty of every man conversant in agricultural subjects, when these are brought into general discussion, to deliver his unbiassed opinion, and to come forward with all the information of which he is possessed; although this may lead him to the unpleasant task of animadverting on the opinions, researches, and conduct of others; and sometimes even of censuring them, when their wisdom or utility appears questionable. Farther than this we have not intended. Measures, not men, have been our object. Belonging to no faction, we have declared our sentiments 
freely. And when we consider that the Board of A sriculture is composed of the chief landed interest of the kingdiom, and therefore men, the sincerity of whose intentions camnot be suspected, we doubt not that the attempts of every individual towards the amelioration of the soil, and the improvement of the var ious requisites of husbandry, will be received by thein with can'our and attention. If we shall, then, be found to have added a mite to the previous stock of the agricultural knowledge of the courtry, we will deem ourselves amply rewarded for the present hasty skctch p:esented to your Lord ship: and we shall continue with diligence our pursuits, uniting theory with practice, and communicating to the public at large, as occasion may offer, the result of our inquiries, when these appear to us to prove beneficial to our countrymen. 


\section{$[97]$}

Since the preceding shects were committed to the press, we have perused Mr. William Brooke's pamphlet, entitled ' The true Causes of our present Distress for Provisions,' \&xc. \&c. dedicated to his Majesty.

This theoretical writer knows but little of the subject upon which he treats. Nor are we disposed to follow him minutely through his speculations. That we shall reserve for a future opportunity; contenting ourselves, at present, with remarking on the most prominent features of his work.

It has been always considered, by the most profound legislators of both antient and modern times, that it is unwise in a state to interpose its authority in making minute rcgulations in matters of domestic policy, the good and evil of which, if left to the operative hand of of time, will, at no very remote period, be regulated and balanced in the consequent result. The utmost extent of human wisdom is so extremely limited, and man is so rarely endowed with sufficient foresight to discover the future by the present state of things, being confounded by the per- 


\section{[98]}

petual evolutions which they are every day performing before him, that interferences of this nature must always be weighed with great doubt, and set about with extreme caution, least we should fix too narrow bounds to industry, and cramp the pinions of genius.

The first recominendation of Mr. Brooke, in order to restore the country to plenty, is to destroy what he calls the 'monopoly of farms:' that is to say, by legislative authority to reduce the size of them. This is an old topic, and has been bandied about for many years, or as often as there has been any material alteration in the price of provisions. Mr. Kent, some years ago, in his publication of " Hints to Gentlemen of Landed Property, laid down a very judicious scale for the different sizes of farms, in order to accommodate farmers of every degree of capital; and from our knowledge of England, we verily believe that principle is acted upon by the most considerable part of the landed proprietors. But, as this is a matter of opinion and assertion, we will place the plan upon its own merits. 


\section{[99]}

Does Mr. Brooke apprehend that the counties of Norfolk and Suffolk, Nottinghain Forest, and many other tracts of barren land, would have been marled, cultivated, and improved by occupiers of small tracts of it, who were neither possessed of capital nor any ability to embark in concerns of great present expence, with a view to call forth, from the bowels of the earth, its hidden treasures?

Has Mr. Brooke reffected, that in order to divide large farms into small ones, with any possibility of advantage, each farm must possess a dwelling-house, barn, stable, and other out-door conveniences; that the magnitude of such buildings does not necessarily increase progressively with the quantity of land allotted to them; that is to say, it requires but little more expence to build properly upon a farm of 1501. per annum than on one of 701 ; that, to reap benefit from such farms, they must be subdivided into at least as many different fields or parcels as there shall be different shifts or different crops cultivated in a regular routine of cropping ; i. e. in most cases either four, five, or six closes? 


\section{[100]}

Does Mr. Brooke reflect on the enormous expence of these procedures? Does he understand that, in order to carry his plan of subdividing farms into execution upon a moderate scale, it ma be fairly calculated that the expence of the measure would more than swallow up the wobole of the life-interest of all the landed proprietors in England?

Does he understand, that in laying out small farms, the quantity of profitable land taken from arable and pasture which is now in cultivation, and thrown into fences, (producing nothing but game and vermin to eat up a great portion of the remainder) will be at least one-twentieth part of ail the land in Engrland? a circumstance of itself sufficient to contribute in no small degree to wards a scarcity.

Does Mr. Brooke recollect the additional annual payment that the landed interest must lay upon the renters of estates, in consequence of such proposed expences of building, fencing, \&c. and that that incumbrance, as weli as taxes, and all other outgoings charged upon the occupier, must be laid by the farmer upon the different articles of the produce of 


\section{[. 101$]$}

the farm, and must be uitimately paid by the consumer? In which case the high price of the articles of consumption must be rivetted to them for ever, without any possibility of seducion.

Does Mr. Brooke recollect, that all kinds of bailding materials are at a very high price in this kingdom, and which have not been a little increased by the Minister having kindly ' laid his fingers' upon bricks, fir-timber, Erc. \&uc.? As Mr. B. scems so alert at recommending laws to be made and broken, it would be a blessing to the country if he would persuade the Minister to take his fingers off all kinds of building materials in any way employed in agriculture; bccause, in a number of indirect ways, those very taxes ultimately fall upon the poor, by the consequent increased price of those necessaries of life which are pioduced from the landbread, milk, potatoes, beef, and mutton.

Probably Mr. Brooke will, at the same time, recommend the Legislature to make up the deficiency, which would arise to the revenue from this measure, by a double tax 


\section{[ 102$]$}

upon building materials used for all other purpses, which would possess the additional advantage of operating as a prohibition of excessive building, by means of which many of the heads of families in the kingdom are very materially injured, and the younger branches left without provision, whilc architects are enabled to quit their own sphere to become borough-mongers and politicians.

If it were necessary, we could exhaust the patience of our readers with multiplied instances to prove that the different sizes of farms will vary according to the capitals of the farmers, at different periods, and the nature of the respective soils to be cultivated. At this moment, when the extended cultivation and drainage of immense tracts of forests, commons, heaths, fens, moors, wastes, and land to be reclaimed from the sea, will demand industry, talent, genius, and the liberal expenditure of capital, to improve them, to propose the limiting the size of farms is a most wanton exercise of theoretical opinions.

The next subject is " the immense number of horses kept in this lingdom." 


\section{[ 103$]$}

The gralual progress of the acquisition of wealth has, in the natural consequences of all human efforts, introduced a refinement and extent of luxury into this land, not surpassed in any age or country, and that is hurrying us on to the natural result, the lot of all sublunary institutions. But how is this to be avoided? We may as well call upon a seasoned dram-drinker to leave off that practice, and to take water in its stcad, as to succeed in recommending the affluent in this country to lay down their superfluous carriages, routes, hounds, and horses. There are innumerable arguments to be used why (if it could be accomplished) it would defcat its own purpose. There would be but little incitement to industry and that spirit which stimulates the British merchant and manufacturer to traverse the world around, if $\mathrm{Mr}$. Brooke was to take away the means of gratifying vanity and ambition, the source from whence they spring. It would be ver y impertinent of him to say to our most gracious Sovereign, " a pair of horses will draw you to Windsor, if you will allow yourself forty 


\section{[104]}

minutes more time upon the road'-to that best of gentlemen-whips, Mr. Robert Allen, - confine yourself to your sulky little gig with one horse, instead of parading up and down St. James's-street in your phaeton with four'-to Mr. Pitt, " instead of that post chariot, drawn by four horses, obtain one of your brother Stanhope's steam engines to work it; or any such like ridiculous propositions. Wealth will produce luxury, and luxury will hold fast to all its modes of gratification till the arrival of the last hour.

It is well known that men are governed more by shades and appearances than by intrinsic worth; because so few there are who are capabie of discriminating and judging of true merit, and fewer who will give themselves the trouble to search for it. It is a well known fact, that before a physician, or apothecary, in London, obtains great professional business, he must, first, provide an handsome cluariot and pair of lean borses.

We have heard it asserted as a truth, that a sallad-dresser calls in his carriage at the houses of several noble families daily, a short 


\section{$[105]$}

time before dinner, to dress their sallads, for which operation he reccives a pice of grold.

Let us impress upon your Lordship's mind, that when the Minister put his finger upon ' horses' employed in agriculture, he was rot aware that the farmer must add every fartling of it to the price of bis corn, cattle, and otber productions, athich must ultimately be laid upon the consumers of all descriptions.

We have already said a few words upon the comparative benefits of employing oxen and horsés in agriculture, and there we would have left that subject if Mr. Brooke had not called forth a furtlier remark upon it by his recommendation to keep oxen till they are six or seven years old. Could any theorist ripon earth have hit upon a plan of reducing the number of neat cattle, and consequently enhancing their price in this island, so effectually as by keeping them to nearly double the necessary age? If we can get an ox to grow to a full weight at four years, at least one-third more may be produced upon the same spot in a given time, than if we keep them 
the time Mr. B. recommends. This gentleman divells constantly upon the absurd theme of increasing the brced of cows. It will soon, we presume, be found that the ox is the least profitable animal in common use in our island, for the very reason which Mr. Brooke commends him. The great object by which the public shall obtain plenty at a lower price, and by which the farmer shall obtain a due proportion of profit, is the making our land produce the greatest weight of corn and animals in the shortest time. The hog stands first, he arrives at perfection at one year oid. The amateurs in the breeding of sheep hope to get the new Leicester sort to perfection at two years old. The ox cannot be considered in perfection, we fear, at four; therefore he is double the time in making a rctum, and on that account the less profitable, and more especially (except in some choice breeds) as his consumption of food is considered to be in a due ratio with his accumulating size and weight.

The quantity of cows, butter, cheese, \&c. 


\section{$[107]$}

will, as before alluded to in these pages, bear a due proportion in a given tme to the price of corn, which governs in great degree the price of all other articles of consumption for man and beast. The inclination of man in every occupation disposes him to pursue the cultivation of those articies which promise to be the most profitable to him, and when one preponierates a little in price, the other rises; and then again they change sides, zice versa.

The story of the Dutch landlady proves only that hor land was superlatively good, and sle was a good manager of her dairy.

Mr. Brooke has in more than in one place in his pamphle, glanced at a commutation of tythes, or a less exceptionable mode of providing for the clergy of the established religion. If the Bourd would recommend Mr. Brooke to turn this subject deliberately in his thoughts, and to give in his ideas before the next scssions of Parliament, something valuable might be produced from him: for the present we shall only owserve, that if 


\section{[ 108$]$}

any change takes place in the mode of paying the clergy for their spiritual labours, we must give them an equizalent, and when that is properly estimated and allowed, the landed interest will not gain any thingr by the change. If you give them less than an equivalent the. chunge will be unjust, their tit'es being as good as any other to landed property. Any innovation, thercfore, which shakes the one, will not fail soon afterwards to destroy the other. - Landed property has descended, and has been bought and sold for a vast serics of years, sibject to that outgroing. In the hands of the laiety, tythes in lind are paid withont grumbling; but whenever a parson takes the full measure to which he is entitled, beth the land-owner and the farmer conspire against him. The reason appcars to us to be, that the clergy rarely get their ducs; and, therefore, whenever any one looks sharp after his interest, his conduct excites clamour and ill-blood.

The dishonourable mode of disposing of livings under simoniacal contracts, or under- 
standings, (which but too often prevails) is part of the cause of these unpleasant observations.

There are instances where the obstinacy of the farmer prompts him to forego his own interest, in nine parts of the produce of his farm, to defeat the parson of his in the tenth; but this is one of those evils which will correct itself. The farmer who pursues such a line of condicet for any length of time, must be inevitably ruined; when he will make room for one who will adopt a different line of conchet, and thus profit by the error of his predecessor.

The ton gencral cillivation of bops, as a means of exhausting the necessary manure which ought to be employed in the regular cultivation of a farm, has been already agitated; therefore it only remains for us here to observe, that the proprietors of land, from a regard to their own interest, will watch orer the cultivation of "the suil without any interference of the Legisiature to pass a law to pronibit the cuitivation of hops. That every 


\section{[110]}

farmer should have an orchard, has been long the theme of almost every agricultural writer for thirty years past; but so slow is the progress of speculative improvements, that the practice, however good, has not been far extended.

Pianting apple and pear trees in or ncar hedges would be a bad practice, as the corn and fences rouk be constanty trodden down until the practice should becowe universal.

It cet having been the practice, for a series of years past, for those who cut down timber to plant any in its stcud, it cannot in many counties now be procurcd for ordinary purposes; dependence for it consequently rests upon an importation from foreign countries, burthened with very heavy impolitic duties.

The condition of the cottager we have already enlarged upon; therefore it will be only necessary here to observe, that he must be an additional renter of land, if he is to keep and maintain goats, pigs, poultry, asses, \&c. Sic. 


\section{[111]}

Poultry cannot be maintained without corn; and if a poor man has to buy it, it vill soon cost more to maintain them than they are worth. Goats are very destructive to live fences; and the ass is the greatest of all nuisances when placed in the way of them; he browses upon the young shoots; and so far from contenting himself, as this author asserts, ' upon the coarsest food,' he is always seeking the most delicate.

This autbor may conceive tea to be a poison, but it is a poison which has long been dealt out very plentifully to the people of this country, and we do not find that the tars, who, whan at sea, use this beverage very plentifully, fight much the worse for being so poisoned. Any legislative prohibition of the use of it, or substituting chocolate, would not at this time be very just or politic, after what the Minister has so recen ily receivedmillions, as a fine for the renewal of the East India Company's charter to vend it in this country. Besides, it is become a great object of revenue. 
We have already mentioned the effeets of a general cultivation of potatoes upon the farms of this country; therefore Mr. Brooke's recommendation, "that occupiers shall be compelled to produce them largely; will, we presume, have no avail.

Nor with more success, we apprehend, will gentlemen be prevailed upon to make their families eat, once a-weck, salt fish, soup meagre, \&xc. \&rc.

We perfeetly agree with Mr. Brooke in recommending legislative interference with regard to the improvement of fisheries upon the coasts of this Island, and in recommending more attention than at present to the properly stocking all the internal waters of the conntry whatever. Also that Billingsgate market should be rendered more open, and forestaling and engrossing effectually prevented; and that the number of such markets should be increased, with due encouragement to small venders of fish.

We are at a loss to undersiand what Mr. Brooke means by the enlarging the meshes 


\section{$[113]$}

of the salmon nets a quarter of àn inch, because that space will make but little difference in the size of a salmon; it will hardly determine whether it shall be caught of twelve or of thirteen pound weight, or such like proportion.

We agree with Mr. Brooke, that our soil is not generally applied to its right use, and that it does not often occur that gentlemen of landed property understand prafical husbandry,-but they think they do.

We are sorry the poplar and larch have so much offended Mr. Brooke; either of them " will pay for a horse before an cak will pay for a saddle.' These are both fast growers, and very useful woods in repairing and improving estates, and we ought to cultivate them. From very recent experinents made by the Duke of Bedford at Woburn, it is proved that the bark of the poplar stands next in rank, and nearly in value, to that of the oak. In a due application of all the soils to their right use, we have no doubt that 


\section{$[114]$}

both the poplar and larch will have places assigned for them.

This gentleman recommends ' the setting, or dibbling' our wheat crops by hand, instead of sowing it broad-cast. The experienced Secretary to the Board, at the Duke of Bedford's sheep-shearing at Woburn in 1798 , made the most public declaration, that he was perfectly convinced it would be more for the public good, as well as that of individual farmers, to sow all our grain broad-cast. He was particularly pointed against drilling, and consequently against dibbling, or setting, which is only a slower and more expensive mode of drilling, and cannot be preferred, except upon land immediately broken up from turf.

Though we approve the practice of drilling and setting wheat by hand to a certain extent, we do not coincide with all the arguments of Mr. Brooke in favour of the practice, and particularly for a more cxtended employment of the poor in the production of grain; because all the extraordinary labour 


\section{[115]}

and expence emplyyed in the cultivation of our land must be charged upon the produet in corn, caltle, $\mathscr{S}^{2} c$. $\mathcal{E}^{2} i$.

Mr. Brooke's plans for the employment of more inhabitants unfortunately have' an ultimate tendency to a result very different from what he recommends. The laying aside spinning by hand, and adopting niachines, and other means of diminishing the quantum of manual labour employed in our manufactories (with some other coinciding circumstances) at present give us an advantage, in a competition with foreigners in their markets, which would not probably be the case without these, even if bread and meat, and consequently labour, were now as cheap as at any period within the last century.

Population has encreased rapidly, notwithstanding all the immense improvements in mills, engines, machinery, canals, \&x. the plainest of all demonstrations, that such works of art have not cherked population, although they may have directed the efforts 
of the inhabitants to new pursuits. It is now well known, that every production estimable amongst us bcars a price according to the quantum of labour and risk employed in producing it. Gold itself is purchased by labour in the mines of Mexico and Pert, where it frequently happens that the quantum produced is not worth the toil of obtaining it, and, on that account, particular mines are frequently discontinued to be worked; that is to say, that the quantum of ore produced will not pay the interest of the ce pital employed, the risk, and wages for the miners, to enable them to purchase food. Every calculation beats principally upon the price of food for man. Gold and silver, but principally gold, is the srreat desideratum which tends to erqualize the value of real and personal property in every part of Europe at least. An immense credit, obtained by certain names upon paper, in any country, may have equal currency with gold, as long as the inhabitants believe that the venders an, when called upon, produce gold for it. 


\section{[117]}

The moment that belief is withield, and compulsive legislative acts are resorted to, to enforce it upon tle community, it will soon bear a progressive degraded cisccunt, and at length will be blown into the air. Goid will always preserve its general intrinsic value; and if the best of paper was not so much more portable and convenient in commercial and other. transactions, between man and man, no adventurer of common sense would touch it. A thousand arguments might be adduced, to prove 'that the cause of the main and fundamental evil which is gradually overtaking, and which will eventually overwhelm this country, is an unlimited paper currency, which, in as many different chameis, boih direetly and indirectly, tend to enhance the price of all the necessarics of hie; and it is the ingenuity alone displayed by our manifacturers in ibe construction of mills and macbiniery, which enables us, for the present, to counteract its baneful effects, and to maintain our trade for manufactured goods in foreign markets, 


\section{118$]$}

and to support millions of industrious inhabitants of this country.

The recommendation, that we should make our cattle cat all our straw instead of using a part of it for manure, which is generally praćtised, is very short-sighted. More bullocks might, indeed, be produced by the measure; but it - is well known by practical farmers, that the excrements of animals fed upon straw contain very little of the essential qualities of good manure; that the quantity or substance is reduced to one-fourth; and, in situations where no other means can be resorted to for manure than what is prodiced in the way recommended by Mr. Brooke, the crops of corn and grass must be diminished exceedingly, and, of course, a scarcity of the food of man and animals will be the consequent result. The saving of manure in towns is daily increasing in practice.

Mr. Brooke's hints, that as a means of diminishing the excessive number of horses, 


\section{$[119]$}

and increasing the number of men in this conntry, the lower order of people, like those in France, shall perform certain portions of labour instead of horses, shew him not to be fully acquainted with the character of the English. We wish to avoid being led into a discussion of political subjects, but we cannot help observing, that yoking, galling, and goading, are experiments which had better not be tried. We are not without instances of their being productive of the most dreadful results.

If any proof is now required, that $\mathrm{Mr}$. Brooke is a mere Theorist in Agriculture, we shall instance his remark, that " the too common prastice of putting sheep into pasture land, where cows are kept or intended to be kept, is totally wrong It is a well known fa? that no animal bites closer the fine and sweet herbage than the sheep, even to the root.'

To any one who understands stocking of land properly, it will not be unintelligiblethat there is not a spot upon the globe where 


\section{[120]}

we can maintain a large head of sheep and a dairy of cows at the same time, and for both to thrive--ihat a certain quantity of herbage can only mintain a certain quantity of mouths to feed upon it - that it is not a common practice for dairy farmers to run sheep amongst their cows at the time they are in full milk-but yet, upon good land a small proportion of sheep would be no evil. It is the abuse of the measure, and making sheep the principal stock upon a dairy farm, that will render it unproducive. The best possible use which can be male of such farm, in order to preserve the herbage fine, sweet, and wholesome, is to lay on a large head of shcep as a second stock in the latter part of the year; so that, accoring to the warmth, strength, and forwardness of the spring, they are not continued so long there as to partake of the first spring grass, or prevent its growth for the use of cows.

The horse having two rows of projecting teeth, bites the cotyledons of the plants, and upon very short pastures frequently does 


\section{$[121]$}

great injury. The sheep has only one row of teeth, less prominent, and very rarely injures the stamina of the plant.

The best mode of stocking rich grazing land is with such proportions of sheep and oxen as will keep the herbage eat down tolerably even, observing to lay on such proportions that each sort thrives equally.

In some districts, where the pasture land is more particularly adapted for the maintaining of sheep than oxen, it is, nevertheless, necessary to put some lean store or working beasts (where ox teams are kept) amongst sheep, to eat any coarse herbage which the sheep may reject.

The incitement to benevolence recommended by Mr. Brooke, for gentlemen to ameliorate the condition of the poor, that - if times of revolution should take place, by behaving condescendently and benevolently to the poor, the most powerful and ungovernable instrument is taken out of the hands of the ambitious demagogue.' This gentle- 


\section{[1.22]}

man wonld make but an indifferent statesman.

The experience of all ages has shewn us that nothirg will be so powerful a preventive of such a dreadful mcasure, as proving to the lower orders that their condition is sucls that it camnot, under any other mode of government, be improved. But when it is afloat, nothing but manly strength and firmness can resist the torrent, and temporizing, by ' condescension and benevolence,' will add courage to the assailants. Gratitude is but little practised by oven the learned and refined, but by the lower orders it is scarcely known by name.

We ntterly disapprove of Mr. Brooke's recommendation of Ministerial interference on agricultural subjects. From what has been already imparted in these sheets, it may be plainly discovered, that the indirect interference of the Ministry has already contributed in part to the production of the evils and calamities which $\mathrm{Mr}$. Brcolie, as well as ourselves, are, to the extent of our abilities, 


\section{$[123]$}

endeavouring to palliate, if we cannot remedy.

It here occurs to lis to remark, that the excessive duty upon salt is one of the principal causes of the present high price of provisions. It is an insurmountable barrier against the improvement and extension of our fisheries, which otherwise would afford employment for the surplus of our population, driven from manufactories by the recent use of machinery, \&c. and thus constantly provide a nursery for our Navy. With regard to the curing of pork and other meat, cheese, butter, \&x. \&c. in seasons of tolerable plenty, as a provision against scarcity (in which the cottager is mosi materially interested) the price is so extremely high, that it amounts nearly to a prohibition of its use. This duty has a similar tendency to enhance the price of provisions in whatever way salt is employed in agriculture, whether as a manure, in the preservation of hay, \&x. \&xc. 


\section{[124]}

WE have already swelled this publication beyond the limits we intended in the outset to prescribe for it; but a subject so interesting to the public, branching out into so many various considerations, and on which not only the dearest interests of the country, but its very existence depends, could but call forth continued observations, when we found the authority of the Board of Agriculture committed in a panegyric upon Mr. Brooke's puerile remarks upon the present supposed scarcity of corn. *

We shall be ready to take the field, whenever called upon, in defence of the foregoing

* See the following advertisement which appeared in the daily paper called the Times, May 23, 1800 :

- BOARD OF AGRICULTURE, Sackvile-Street.

- resolved,

- That the thanks of this Board be given to William Brooke, Esq. for his pamphlet on the high price of provisions and the Means of Removing Scarcity.

- Ordered to be preserved in the Library of the Board:

NEWARK, Y.P." 


\section{$[125]$}

observations and opinions, as well as in that of the following positions:

That the self-created institution, the Board, had its origin in excessive zeal, but not in talent to improve the agriculture of this country.

That its principal officers were appointed from interest, without considering the requisite talents.

That its subsequent exertions have not materially tended to correct its original errors.

That the natural consequence has been, that the objects upon which it has been employed for eight successive years, "with a revenue of soool, per annum, have, from causes already assigned, been chiefly unsuccessful.

That the only object attained has been the rousing a spirit for agricultural improvements, a measure which was or might have been effected in the first twelve months of the institution.

That the spirit which might have been 


\section{$[126]$}

excited, and the good which the public might have derived from an agricultural institution properly grounded, has in a great measure been lost by the too apparent imbecility of the exertions of this.

That the public has paid or is pledged to pay 1000l. to Mr. Elkington for the discovery of a professed secret in the art of drainage which was practised by Dr. Anderson, and published by him twenty years since.

That the attempt to improve the breed of cattle and sheep was not proceeded upon in a proper manner.

That it would have been more proper to have contemplated the peculiar properties of each variety of animal in the several districts, than upon any limited and partial grounds to have considered only the peculiar perfections of a few.

That the Board has not pursued the proper ineans of discovering the wise intentions of Nature why horns were given to animals of one district and withheld from those of 


\section{$[127]$}

another, together with the peculiar corresponding qualities of wool, flavour, \&c. \&c.

That from the result of such enquiries a firmer basis would have been laid for rational subsequent improvement, than in selecting one or two varieties of sheep, merely from a própensity to generate tallow upon the carcase.

That the Board has sanctioned, or suffered the overheated imagination of its Secretary to commit its responsibility upon false and theoretical principles, recommending modes of practice to farmers, which, if adopted, would be productive of all the evils he proposes by his pamphlet on the present 'Scarcity' to remedy.

That the Board has discovered to the public either a tutal want of discrimination upon agricultural subjects, a total want of consideration for the public good, or an utter contempt for its respectful opinion, by the publication of a large volume of Communications of 1799 , chiefly setting forth, as new 
discoveries, modes of practice which have been adopted for a great length of time; with crude speculations upon subjects of secondary importance, without any actual benefit likely to arise from the result. It is what, in the language of Booksellers, is commonly called 'Bookmaking.'

We conceive that a great national institution would have deserved well of the country had it first employed itself with industry and care to select and call forth all the talents in the united kingdoms to assist in comprehending and discriminating the primary objects to which its attention should have been first directed; and the most successful means to have been employed in carrying well digested plans of agricultural improvement into effect, rejecting the consideration of all party views, calling forth genius, united with experience, wherever found, whether its dawn commenced on this or on that side of the Tweed. It might then repose upon the dignity of its own character, the rectitude of 'its conduct and of its operations, laying aside 


\section{$[129]$}

altogether the childish vanity of establishing a borrowed reputation by meddling in the minutix * of a science, the understanding of which is denied to it by education, early pursuits, and more exalted habits of life.

Had this great national institution been governed by such motives, and directed by such views on the outset in 179 , we should have now the attainment of the following objects $i_{1}$ no distant view.

The competent drainage of millions of acres of fens, marsh lands, + low lands, and all other lands and grounds now unproductive, and receiving constant injury from water, and in particular instances turning that element to the improvement of the soil instead of being its greatest enemy.

* This propensity may not be inapplicably compared to a passenger in a stage-coach, who, not contented to sit still, and to have the velicle driven safely by the accustomed coachman, who knows the temper of his cattle, and the turn. ings and windings of the road. must mount the box, and take the whip, by means of which the whole are overthrown.

+ Of all land, the most prodtctive when drained, one acre of which would be equal in produce to ten of heath land. 


\section{[130]}

The security of embankments made against rivers and the sea, to the utmost extent of human foresight.

The embankment and cultivation of large tracts of sands and washways now open to the sea and to the tides.

A more general and systematic discovery of the contents of the bowels of the earth in different districts, as to ores, coals, manures, and means of improving the surface.

The promotion of canals.

The separations of interests in, and the inclosure and cultivation of his Majesty's forests.

The inclosure of commons, common fields, and waste lands.

The sale* of the Crown lands.

* It has been rumoured that Mr. Fordyce, the SurveyorGeneral, gives out that he shall advance the annual income from this estate to 400,0001 . per annum. Be it so. For the reasons already given in this publication, there is the strongest. ground to believe, that such species of improvement will be rebutted by restraints, depressions, and oppressions that will ultimately diminish the revenue in an equal ratio. 


\section{[. 181$]$}

The application of all the various soils to their most profitable uses, whether in arable, pasture, or wood.

Encouragement for the discovery of new manures best adapted to the various soils.

Let any man of common sense deny, that if proper attention had been paid to these objects in due time, the words SCARCITY of provisions, without monopoly, could not now be in the mouth of an Englishman.

\section{CONCLUSION.}

WE shall conclude with the following observations, suggested more, indeed, by our knowledge of the people of this country than by our acquaintance with the history of mankind. And although by some men we may be considered for once to be a little speculative, we are persuaded, that, should the efforts of those invested with power be directed to call forth into action the latent springs of internal improvement to their 


\section{[132]}

utmost capability, by example and adequate encouragement, greăt ultimate good would accrue to the British empire. If by this its stability, greatness; and prosperity could not altogether be made certain, they would at least belengthened to a remote period of time. An ara more apposite than the present for using rvise precautions has not occurred in its history,-when a general movement towards a change seems to pervade the greater portion of civilized society, - when a most powerful nation in population and internal resources, armed with the thunder of war in one hand, and the magical rod of opinion and persuasion in the other, has shooli the world like a tempest, and threatens to overflow it like a torrent.

In the cultivation of the soil, as we have repeatedly declared, the real wealth and per. manence of nations consist. This is not our opinion alone, for it is sanctioned by that of the wisest philosophical economists of ancient and modern times, who, fortunately for human society, have of late bent their minds to 


\section{[ 133$]$}

to the investigation of this important subject more than in any former period. And happy would it be for Britain, if the baneful predominant spirit for foreign commerce and colonization were somewhat restrained, and a portion of the capital and industry employed. in it were diverted to the cultivation of the soil, and to the amelioration of the condition of its inhabitants, before it is too late to avert the impending evil.

Trade, like its clement the sea, has a certain pitch above which it never rises in the highest tides; and it begins to ebb whenever it ceases to flow; and always recedes in one place in proportion as it gains in asother. It would be wise, therctore, in this country to examine with a discriminating eye whether or not its commercial tide has arrived at its utmost height.

To be convinced of the futurution and instability of commercial greatness, we have only to take a retrospective glance of the history of Tyre, Carthage, Athens, Sjracuse, Agrigentum, Rhodes, Venice, Florence, Lis- 


\section{[ 134$]$}

bon, the Hans-Towns, Antwerp, and Holland. We shall there find, that the prosperity and the wealth of each declined when a rival arose ; and in proportion as other states became their own carriers, the tides of these ebbed in succession, to flow no more. Their great opulence, on which alone depended their existence, excited other nations to their conquest; while the consequent luxury and dissipation of the inhabitants, by weakening their attachments and enfeebling their characters, hastened and facilitated their final destruction. Agricultural pursuits, on the contrary, not only invigorate the body and mind, but foster and preserve local attachments, and incite gratitude to that soil to which we are taught to trust for the comforts of life.

In illustration of this subject, we shall content ourselves with citing one instance from the history of the latter nation, as being more recent, and consequently more within the recollection of our readers.

The Dutch are recorded by Roman and 


\section{[ 135$]$}

other writers of the greatest veracity, as the bravest among the Germans, and the most obstinate lovers and defenders of their liberty. They maintained this character till the application they had before bestowed on agriculture, and the arts dependent on or connected with the soil, was almost exclusively turned to foreign commerce and trade. With this important change commenced the decline of the Low Countries. A particular instance of the degeneracy of their character occurred, if we recollect right, about 1567, when the arrival of the Duke of Alva with an army of only twelve or fourteen thousand men, had spread so great a panic, that upwards of one hundred thousand families, composed wholly of merchants and traders, withdrew with their money and property from the country.

But in what country, and on what occasion can it be found, that an equal or much less number of the cultivators of the soil have been so easily intimidated, or have so basely deserted their country in the hour of 
danger? What have the Swiss done on similar occasions? To the enervation and profligacy introduced by trade and foreign intercouse do they owe their late misfortunes.

The inquirer into physical and moral causes has observed, that the peasant, who depends for his subsistence, however scanty, on the means derived by his labour from the cultivation of the earth, and the useful arts immediately connected with it, is attached with more lasting sincerity to his native reregion * than the artizan or the trading inha-

* 'The late Empress Catharine of Russia succeeded, after much persuasion, in inviting a colony of Laplanders from their own miserable country to settle in a district of the most fertile soil and genial climate on the borders of Poland. Although she provided them with comfortable habitations, inplements of husbandry, and every other requisite for an infant colony, yet so great was thcir regard for their native country, and so constantly did it prey on their spirits, that they gradually pined away to a small number, who at length, after repeated solicitation, obtained leave to return home.

Many more instances of local attachment in the peasantry of a country might be cited from history, both ancient and modern. But the discussion of the Slave Trade, so recent in the rccolleation of cur readers, has afforded a sufficient num. ber. 


\section{$[137]$}

bitants of great towns; the farmer, than the mere merchant; and the landed gentleman resident on his estate, than the polished gentleman or courtier of town.

Although we do not pretend to dive into the causes of this distinction, yet we cannot avoid offering a few reflections, leaving it to the philosopher, whose province it is, to pursue the inquiry farther.

The inhabitants of great towns,-whether from frequent social intercourse with diversified society, from conversation, from commercial habits, from the p culiar air of citics, from all these combined, or from some other cause,-are more mercurial, of warmer brains and quicker spirits, more airy and volatile, and more ready for innovation, than the labourers of the suil or others living in the open country, whose spirits being inore carthy or dull, thought in them moves slower and heavier, but thereby the impressions of it are decper, and last longer ; one imayinatiun being not so frequently nor so easily 


\section{[ 138 ]}

effaced by another, as where new ones are continually arising. With the heat of the brain, it may be presumed, passes away also a great portion of that of the heart. Hence, perhaps, the diminution of attachments. The former, too, are generally more idle, more versatile, subject to fits of the spleen, and conscquently more easily led into speculative notions or siluemes of general bappiness.* Let us only examine the history of the French revolution, without reverting to innumerable other instances in the records of past times, and we shall find that cities have formed the hot-beds of innovation and sedition; and that in the various attempts to transplant

* In all large towns there is a great infux of foreigners, of various nations, and of difierent tempers and dispositions, as well as of intelleclual and moral qualities. To reason from analogy, may it not be presumed, that the constant inter mixture of these by marriage (or what we farmers call crossing tbe breri) "ith the native inhabitants, the collision of minds, and the influence of association and manners, operate at length as physical and moral causes in changing the original character of the latter? 
these into the champain country, either from the want of congeniality of climate or soil, they have been frequently nipt in the bud; and, where they have taken root, their growth has been very slow.

We are therefore persuaded, from our own experience and observations on this subject, that there is someother cause, equally powerful with that of self-interest, for this distinguishing feature of both classes of the community. It may indeed be composed of a variety of minute particles, too subtile to be easily discerned by our limited comprehensions.

We will not, however, hesitate to arsert, and we are warranted by incontrovertible experience, that the empire or state which devotes its chief attention to agriculture and internal improvements, is not only the most happy, but the most powerful and durable. For proof of this position we beg leave to refer the intelligent part of our readers to the history of the Chinese empire, which stands unrivalied, in the amnals of the world, for both. There agriculture is the primary 


\section{[140]}

object of all, from the Prince to the mornest of his subjects.

These hints, therefore, important cnly as far as they are true, we recommend to the mature consideration of your Lordship and the other members of the Board of Agriculture, begging that you will impress them strongly on the minds of men in power. And we call on the united exertions of all men of rank, talents, influence, and property to co-operate with you in extending the practical knowledge of that science to which all others are subordinate, instead of wasting your time on frivolous pursuits or airy speculations.

A theory without experience or practice stands upon no basis: it resembles a beautiful tower built on a volcano, in perpetual danger of being blown up or of sinking in the abyss. Cherish and encourage, then, the practical husbandman, that he may instruct and guide your sons to the true path of national happiness. Let agriculture be the primary object of all; not only because it 


\section{[ 141$]$}

' creates a more plentiful supply of food, but as morally and politically conducing to the true happiness of man, by giving him the occupation whence flow health, social order, and obedience to lawful authority.' For how contemptible do the brightest pursuits of Fame appear when opposed to the simple merit of doing good to mankind!

FINIS.

FRINTED BY G. CAWTHORN, STRAND. 


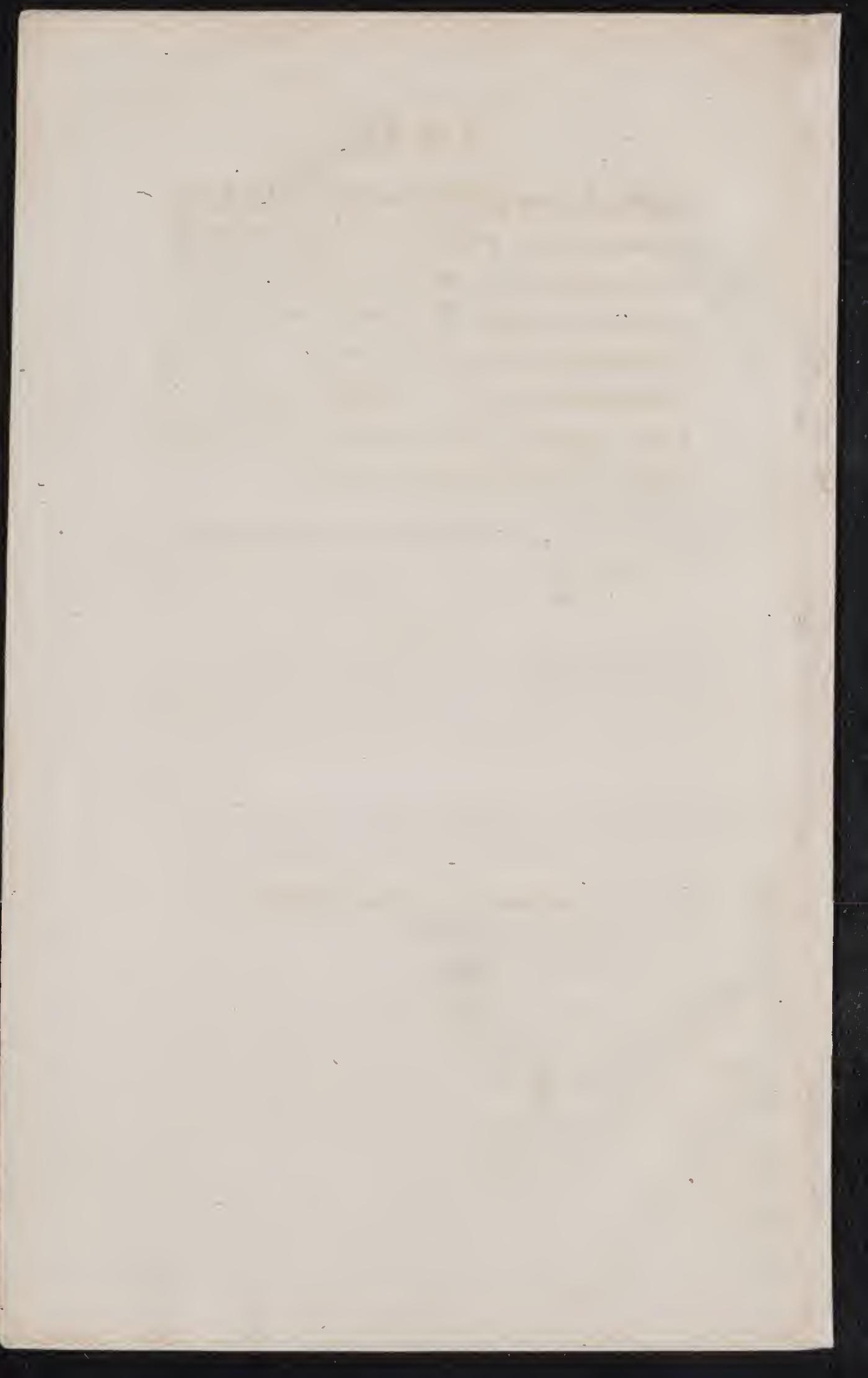

